\title{
Proliferative Effect of Aqueous Extract of Sea Cucumber (Holothuria Parva) Body Wall on Human Umbilical Cord Mesenchymal Stromal/stem Cells
}

\section{Poorya Rasekh}

Bushehr University of Medical Sciences

Ali Kameli

Bushehr University of Medical Sciences

Arezoo Khoradmehr

Bushehr University of Medical Sciences

Neda Baghban

Bushehr University of Medical Sciences

Gholamhossein Mohebbi

Bushehr University of Medical Sciences

Alireza Barmak

Bushehr University of Medical Sciences

Iraj Nabipour

Bushehr University of Medical Sciences

Hossein Azari

Bushehr University of Medical Sciences

Yaser Heidari

Bushehr University of Medical Sciences

Adel Daneshi

Bushehr University of Medical Sciences

Afshar Bargahi

Bushehr University of Medical Sciences

Zahra Khodabandeh

Shiraz University of Medical Sciences

Shahrokh Zare

Shiraz University of Medical Sciences

Reza Shirazi

UNSW: University of New South Wales

\section{Sahar Almasi-turk}

Bushehr University of Medical Sciences

Amin Tamadon ( $\nabla$ amintamaddon@yahoo.com )

Bushehr University of Medical Sciences https://orcid.org/0000-0002-0222-3035 


\section{Research Article}

Keywords: Stem Cells, Sea Cucumbers, Cell Proliferation

Posted Date: November 22nd, 2021

DOI: https://doi.org/10.21203/rs.3.rs-1056356/v1

License: () (1) This work is licensed under a Creative Commons Attribution 4.0 International License. Read Full License 


\section{Abstract}

Background: The sea cucumber potentials for stem cell proliferation induction and their mechanisms of bioactive compounds in its extract have been studied. Human umbilical cord mesenchymal stromal/stem cells (hUC-MSCs) were exposed to aqueous extract of Holothuria parva body wall.

Methods: Using GC-MS analysis on aqueous extract of $H$. parva, proliferative molecules were detected. The extract concentrations of $5,10,20,40$, and $80 \mu \mathrm{g} / \mathrm{mL}$ and 10 and $20 \mathrm{ng} / \mathrm{mL}$ of human epidermal growth factor (EGF) as positive controls were used. MTT proliferation, cell count, viability, and cell cycle assays were performed. Using Western blot analysis, effects of aqueous extract of $H$. parva and EGF on cell proliferation markers were detected. Computational modeling done to detect effective proliferative compounds in aqueous extract of H. parva.

Results: MTT assay showed that the 10,20 , and $40 \mu \mathrm{g} / \mathrm{mL}$ aqueous extract of $H$. parva had proliferative effects on hUC-MSCs. Count of the cells treated with the $20 \mu \mathrm{g} / \mathrm{mL}$ of the extract was increased faster and higher than the control group $(P<0.05)$. This concentration of extract did not have significant effects on hUC-MSCs viability. The cell cycle assay of hUC-MSCs showed that percent of cells in the G2 stage of the extract was biologically higher than the control group $(P>0.05)$. Expression of the cyclin D1, cyclin D3, cyclin E, HIF-1a, and TERT were increased comparing with the control group. Moreover, expression of the p21 and PCNA decreased after treating hUC-MSCs with the extract. However, the CDC-2/cdk- 1 and ERK $1 / 2$ had almost the same expression as the control group. The expression of the cdk-4 and cdk- 6 was decreased after treatment with the extract. Between the detected compounds, 1-methyl-4-(1-methylethenyl)-benzene showed better affinity to cdk-4 and p21 than tetradecanoic acid.

Conclusions: The H. parva aqueous extract showed proliferative potential on the hUC-MSCs.

\section{Introduction}

Human umbilical cord mesenchymal stromal/stem cells (hUC-MSCs) as an allogeneic source of stem cells have been clinically studied for skin repair (1). The hUC-MSCs can play roles in skin wound healing phases including hemostasis, inflammation, proliferation and maturation (2). Skin injuries are categorized into superficial, partial-thickness, or full-thickness in terms of the damage caused to the skin structure (3). These injuries can be treated by wound excision, skin grafting, skin substitutes, or wound dressings (3). Introducing proliferative agents into skin wound dressings has the potential to improve tissue regeneration (4). Combination of stem cell therapy and proliferative agents in complementary and alternative medicine can be promising tissue regeneration $(5,6)$.

Sea cucumbers have the ability of whole organ regeneration because they direct their wound healing abilities towards restoring their organs (7). The bioactive compounds producing during wound healing and organ regeneration in sea cucumber may give us the opportunity to repair human wounds. Sea cucumber extracts and their bioactive compounds have been studied for their beneficial therapeutic properties, including anti-cancer, anti-bacterial, anti-viral, anti-diabetic, and anticoagulant properties (8). Recently, different type extract from various species of sea cucumber, have been shown to promote cell proliferation 
in cell lines and/or differentiation of pluripotent MSCs under standard in vitro or in vivo conditions (9-12). Sea cucumber therapeutic effects have been gaining interest in complementary medicine because of their advantages over other semi-biological and synthetic proliferative inducers, such as availability, low toxicity, and comparatively low cost.

We presume that bioactive molecules derived from sea cucumber, could be utilized to enhance the proliferation of stem cells. In this project, we aimed to evaluate the impact of Holothuria parva aqueous extract on the viability and proliferation capacity of human umbilical cord mesenchymal stem cells (hUCMSCs).

\section{Materials And Methods}

\subsection{Sampling and identification of sea cucumber}

Sea cucumbers were harvested alive from coastal waters of Dayyer, the Persian Gulf, Iran $\left(28^{\circ} 57^{\prime} 44.6^{\prime \prime} \mathrm{N}\right.$ $\left.50^{\circ} 48^{\prime} 42.5^{\prime \prime} \mathrm{E}\right)$. They were sent to the laboratory in containers filled with fresh seawater for extraction and further processing. They were rinsed with distilled water to remove debris and transferred to the aquarium with 29 ppt salinity and $26^{\circ} \mathrm{C}$ water temperature. The samples were identified according to identification keys $(13,14)$.

\subsection{Preparation of sea cucumber aqueous extract}

The sea cucumbers were washed with tap water at the laboratory to eliminate all particles from their body. The sea cucumber body was cut longitudinally and taking out all the internal organs. The body wall was washed by distilled water properly then was cut into small pieces. The samples were homogenized using a blender and mixed with distilled water. The prepared mixture was filtered using Whatman filter paper. Following filtration, we freeze-dried the liquid and stored the final powder at $-80^{\circ} \mathrm{C}(15)$.

\subsection{Gas chromatography-mass spectrometry (GC-MS) assay}

The GC-MS analysis was used to evaluate the chemical composition of the sea cucumber extract (16). The lyophilized fractions, were subjected to the 7890B Agilent Gas Chromatography-Mass Spectroscopy. Electronionization (EI) mass spectra (scan range, $\mathrm{m} / \mathrm{z} 50-500$ ) were obtained using electrons with energy of $70 \mathrm{eV}$ and filament emission of $0.5 \mathrm{~mA}$. The GC separations were conducted using an HP-5MS UI column $(30 \mathrm{~m} \times 0.25 \mathrm{~mm}$ i.d., film thickness $0.5 \mu \mathrm{m}$ ). Helium was used as the carrier gas (flow: $0.8 \mathrm{~mL} / \mathrm{min}$ ) for El. The GC oven temperature was programmed at $5^{\circ} \mathrm{C} / \mathrm{min}$ from $80^{\circ} \mathrm{C}$ after $3 \mathrm{~min}$ since the sample injection and held at $250^{\circ} \mathrm{C}$ for $10 \mathrm{~min}$. The injection port of the gas chromatograph, transfer line, and ion source of $5977 \mathrm{MSD}$ were maintained at $240^{\circ} \mathrm{C}, 250^{\circ} \mathrm{C}$, and $220^{\circ} \mathrm{C}$, respectively. The separated compounds were identified by comparing them with the compound data from the National Institute of Standards and Technology (NIST MS database, 2014) library. The relative percent amount of each component was measured by comparing its average peak area to the total areas.

\section{4. hUC-MSCs culture and characterization}


The hUC-MSCs were isolated from infants umbilical cords, and cultured (17). The cells were cultured in 75 $\mathrm{cm}^{2}$. Tissue culture flask (NEST, Cat. No. 708003, China) and incubated (Memmert, INB200, Germany) at $37^{\circ} \mathrm{C}$ with $5 \% \mathrm{CO}_{2}$ in a $95 \%$ humidity cultured in a Dulbecco's Modified Eagle's medium (DMEM) (Gibco ${ }^{\mathrm{TM}}$, Cat. No. 12-800-082, UK) medium containing 10\% FBS (Kiazist, Cat. No. KFBS100, Iran), 1\% penicillin streptomycin (Gibco ${ }^{\mathrm{TM}}$, Cat. No. 15-140-122, UK) and 1\% gentamicin (Sigma-Aldrich, CAS. No1405-41-0, USA) (18).

Flasks of hUC-MSCs were incubated at $4^{\circ} \mathrm{C}$ in dark with either phycoerythrin (PE) or fluorescein isothiocyanate (FITC)-conjugated antibodies specific for CD44, CD90, CD73, CD34, and CD45. Cells were analyzed by flow cytometry using a BD FACS Calibur (BD biosciences, San Jose, CA, USA) (17).

Adherent cells were subjected to adipogenic, osteogenic, and chondrogenic differentiations in vitro, according to established protocols (19). In a 24-well cell culture plate, $5 \times 10^{4}$ cells were seeded and $2 \mathrm{~mL}$ culture medium was added. Then the cells were incubated at $37^{\circ} \mathrm{C}$ in a humidified atmosphere of $5 \% \mathrm{CO}_{2}$. After $24 \mathrm{~h}$, the culture medium was replaced with differentiation media (Kiazist, Iran). Cells were treated with differentiation media for three weeks with medium changes every $3 \mathrm{~d}$. To document the adipogenic differentiation, the culture was rinsed three times with 1X phosphate buffer saline (PBS, Sigma-Aldrich, P4417-100TAB, USA), fixed with 4\% formalin (merck, Cat. No. 1040022500, Germany) for 20 min. Then formalin was removed and washed with sterile distilled water and stained for 20 min with Oil Red 0 staining to stain lipid droplets or Alizarin Red staining to observe the calcium-rich extracellular matrix and observed under the microscope (Optika, Cat. No. IM-3FL4, Italy). For validating chondrogenic differentiation, after removing formalin, the cells were washed with sterile distilled water, and $40 \mu \mathrm{L} \mathrm{HCl} 0.1 \mathrm{M}$ (Merck, Germany) was added. $\mathrm{HCl}$ was removed and $0.5 \mathrm{~mL}$ Alcian Blue was added. After $20 \mathrm{~min}$, the stain was removed and washed twice with PBS 1X. The cells were observed under light a microscope for glycosaminoglycans.

\subsection{MTT (3-[4,5-dimethylthiazol-2-yl]-2,5 diphenyl tetrazolium bromide) proliferation assay}

For the MTT assay $4 \times 10^{4}$ hUC-MSCs were seeded in each well of a 96-well tissue culture plate (Sorfa, Cat. No. 220400, China) and added $200 \mu$ l culture medium then incubate for $24 \mathrm{~h}$ to let cells attached to the bottom of the plate (20). After that, replaced the medium with different doses of aqueous extract $(5,10,20$, 40 , and $80 \mu \mathrm{g} / \mathrm{mL}$ ) after some modification of previous findings (9), epidermal growth factor (EGF) (10 and $20 \mathrm{ng} / \mathrm{mL}$ ) as positive control based on previous findings (9) or culture media as negative control. After 72 $\mathrm{h}$ treatment, the cells medium was removed and washed twice with PBS 1X. Then, $100 \mu \mathrm{L}$ MTT solution (bio-idea, BI-2004, Iran) was added per well and incubate for $4 \mathrm{~h}$. After that, $150 \mu \mathrm{L}$ Dimethyl sulfoxide (DMSO, bio-idea, BI-2004, Iran) was added. The plate was put in an incubator for 20 min. Quantification was then carried out using a microplate reader at $570 \mathrm{~nm}$.

\subsection{Cell count and cell viability assays}

For these assays, $1 \times 10^{4}$ hUC-MSCs were seeded in each well of a 24 -well tissue culture plate and added 2 $\mathrm{mL}$ culture medium. Then it was incubated for $24 \mathrm{~h}$ to let cells be attached to the bottom of the plate (21). 
Then, the medium was replaced with culture media, $20 \mu \mathrm{g} / \mathrm{mL}$ aqueous extract and $10 \mathrm{ng} / \mathrm{mL}$ EGF and replaced it every $3 \mathrm{~d}$. This doses were selected based on the MTT results. Every $24 \mathrm{~h}$, the medium was removed from wells and washed it with PBS 1X. Adding $0.5 \mathrm{ml}$ trypsin-EDTA (Gibco ${ }^{\mathrm{TM}}$, Cat. No. 25300054, UK) and 4 min incubation and then enzyme neutralization with $1.5 \mathrm{~mL}$ by adding culture medium, cell suspension was collected. The suspension was centrifuged, the supernatant was removed and $1 \mathrm{~mL}$ culture medium was added to cells and shaken well to a homogeneous mixture. To count the cells, $10 \mu \mathrm{L}$ of this mixture was pipetted and mixed with same volume of trypan blue and count with a hemocytometer under light microscope. Based on the point that viable cells with intact membranes do not absorb trypan blue stain, dead cells were distinguished from viable ones by their blue color while live cells appeared white.

\subsection{Cell cycle assay}

Treated hUC-MSCs with $20 \mu \mathrm{g} / \mathrm{mL}$ aqueous extract or $10 \mathrm{ng} / \mathrm{mL}$ EGF for $72 \mathrm{~h}$ were harvested at 80-90\% confluence for cell cycle analysis. The cell concentration was adjusted to $5 \times 10^{5} \mathrm{cell} / \mathrm{mL}$. Cells were washed with PBS $1 \mathrm{X}$ and were fixed with $70 \%$ ethanol at $4^{\circ} \mathrm{C}$ for $2 \mathrm{~h}$. Fixed cells were then centrifuged and the supernatant was discarded. Fixed cells were washed and incubated in $1 \mathrm{~mL}$ propidiumlodide (PI) master mix included $40 \mu \mathrm{L} \mathrm{PI}, 10 \mu \mathrm{L}$ RNase (DNase free), and $950 \mu \mathrm{L}$ PBS for $30 \mathrm{~min}$. Cell cycles were assessed by flow cytometry and analysis was performed using FlowJo software (22).

\subsection{Western blot}

Western blot analysis was done based on the standard procedures with slight modifications (23). After $72 \mathrm{~h}$ treatment of hUC-MSCs with $20 \mu \mathrm{g} / \mathrm{mL}$ aqueous extract or $10 \mathrm{ng} / \mathrm{mL}$ EGF, they were used for western blot analysis. In details, cells were lysed by lysis buffer including $500 \mu \mathrm{L}$ tris-HCL pH=8, 0.003 gr EDTA, 0.08 gr $\mathrm{NaCl}, 0.025 \mathrm{gr}$ sodium deoxycholate, $0.01 \mathrm{gr}$ sodium dodecyl sulfate, 1 tablet protease inhibitor cocktail, and $10 \mu \mathrm{l} \mathrm{NP40} \mathrm{(1 \% )} \mathrm{triton} \mathrm{at} 4^{\circ} \mathrm{C}$ for $20 \mathrm{~min}$. The lysates were centrifuged at $12000 \times \mathrm{g}$ for $10 \mathrm{~min}$ at $4^{\circ} \mathrm{C}$, and the protein concentration was measured by a Bradford protein assay. Then, proteins were transferred to microporous polyvinylidene difluoride membrane (Millipore, France). Membranes were incubated in a blocking buffer for $1 \mathrm{~h}$ at room temperature. After blocking, the membranes were incubated with the corresponding primary antibodies separately overnight at $4^{\circ} \mathrm{C}$.

Immunoblotting was performed with $\beta$-actin (c4): sc-47778 (Santa Cruz Biotechnology), cdc2 p34 (17): sc54 (Santa Cruz Biotechnology), cdk-4 (dcs-35): sc-23896 (Santa Cruz Biotechnology), cdk6 (b-10): sc-7961 (Santa Cruz Biotechnology), cyclin D1 (a-12): sc-8396 (Santa Cruz Biotechnology), cyclin D3 (1): sc-135875 (Santa Cruz Biotechnology), cyclin E (he12): sc-247 (Santa Cruz Biotechnology), ERK 1/2 (h-72): sc-292838 (Santa Cruz Biotechnology), HIF-1a (28b): sc-13515 (Santa Cruz Biotechnology), p21 (f-5): sc-6246 (Santa Cruz Biotechnology), PCNA (pc11): sc-53407 (Santa Cruz Biotechnology), and TERT polyclonal antibody eab-33070 (Elabscience Biotechnology). Membranes were washed 3 times (10 min each) in Tris-buffered saline before incubating with m-IgGKBP-HRP: sc-516102 (Santa Cruz Biotechnology) or mouse anti-rabbit IgG-HRP: sc-2357 (Santa Cruz Biotechnology) secondary antibodies. One of the most accurate and sensitive techniques for detecting the desired protein band (identified by its specific antibody) is the use of chemoluminescence kits. ECL advanced reagents kit and its protocol was used.

\subsection{Computational details}




\subsubsection{Preparation of ligands and receptors}

Fifty-eight compounds detected through the GC analysis of the aqueous extract of sea cucumber (H. parva) body wall. Accordingly, these compounds were selected as ligands to study whose interactions with nine target proteins through the docking process. Their three-dimensional (3D) structure downloaded from the PubChem database. Nine proteins of CDK4, CDK6, Cyclin D1, Cyclin D3, Cyclin E, HIF-1a, p21, PCNA and TERT were downloaded from the Protein Database Bank (PDB) with PDB code of 2w96, $1 \mathrm{blx}, 2 \mathrm{w} 96,3 \mathrm{~g} 33$, $7 \mathrm{kjs}, 4 \mathrm{~h} 6 \mathrm{j}, 5 \mathrm{e} 0 \mathrm{u}, 5 \mathrm{e} 0 \mathrm{u}$, and $5 \mathrm{ugw}$. The HyperChem software version 8.0.10 was used to optimize the ligands geometry. All receptors were prepared for docking process using Chimera 1.15.

\subsubsection{Generation of grid box}

The grid box was manually generated with a space of $0.375 \AA$ at the position of the active sites chosen according to the result of the CASTp calculation.

\subsubsection{Study of target proteins-marine derived compounds interactions}

In order to perform the docking process, Autodock Vina 1.1.2 software was utilized to conduct to investigate interactions between receptors and ligands.

\subsection{Statistical analysis}

The data were statistically analyzed using IBM SPSS Statistics 26 software (SPSS for Windows, version 26, SPSS Inc, Chicago, Illinois, USA). Comparison between groups was done using one-way ANOVA and post hoc LSD test (for comparing the MTT and cell proliferation and viability assays) or chi-square test (for comparing the cell cycle analysis and flow cytometry). Data were demonstrated as mean \pm standard error of mean. The significant difference between groups was statistically considered $p<0.05$. The graphs were drawn using Graph pad prism (v7.0a, GraphPad Software, Inc., San Diego, CA, USA).

\section{Results}

\subsection{Sea cucumber was identified as H. parva}

Identification of sea cucumbers was aided by the examination of the skeletal elements (ossicles) found in various parts of the body (Figure S1). Separated ossicles confirmed that the collected sea cucumbers were H. parva based on the identification keys $(13,14)$.

\subsection{GC-MS analysis detected proliferative compounds in the aqueous extract of $\mathrm{H}$. parva}

Sixty compounds were detected in the aqueous extract of $H$. parva via GC-MS analysis (Figure S2 and Table 1). It was shown that the molecules in the aqueous extract from $H$. parva had different biological effects. As it was shown in Table 1, there were two molecules including methyl ester octadecanoic acid (24-26) and 1-methyl-4-(1-methylethenyl)-benzene (27-29) which has been proved to have proliferative biological 
activity. Other biological activities were also observed in other molecules of aqueous extract of H. parva including anti-oxidant, anti-microbial, anti-inflammatory, etc. (Table 1).

\subsection{Morphologic and immunophenotypic assays and differentiation to adipocytes, osteocytes, and chondrocytes confirmed hUM-MSCs isolation}

Morphologically, the MSCs were thin and long spindle-shaped cells with small cell bodies (Figure 1A). The cells' morphology did not change during the four passages. At the molecular level, MSCs did not express CD34 (0.04\%) and CD45 (0.16) (Figures 1B and 1C). At the molecular level, MSCs express surface antigens including CD44 (99.9\%), CD73 (98.5\%), and CD90 (98.3\%) (Figures 1D-1F).

To verify the multipotency of the hUC-MSCs, the cells were assessed for their adipogenic, chondrogenic, and osteogenic differentiation capacities in vitro. In the adipogenic differentiated cells, red-stained intracellular vacuoles were observed (Figure 1G). In osteogenic differentiation, adherent monolayers of spindle-shaped cells became multilayered cell clusters surrounded by a matrix-like substance (Figure $1 \mathrm{H}$ ). In chondrogenic differentiation, at day 21, the cartilaginous elements were numerous and well-differentiated and the cells were observed under the light microscope for sulfated proteoglycan (Figure 11).

\subsection{Aqueous extract of $H$. parva induced proliferation of hUC-MSCs}

The findings of MTT assay demonstrated that the 10,20 and $40 \mu \mathrm{g} / \mathrm{mL}$ aqueous extract of $H$. parva had proliferative effects on hUC-MSCs $(p=0.01, p<0.001$, and $p=0.014$, respectively, Figure $2 \mathrm{~A})$. Moreover, the EGF-10 and EGF-20, as positive controls, had also proliferative effects on hUC-MSCs $(p<0.001$, Figure $2 A)$. In addition, the EGF-10 had higher proliferative effects on hUC-MSCs than the 10 and $40 \mu \mathrm{g} / \mathrm{mL}$ aqueous extract of $H$. parva $(p<0.05$, Figure $2 A)$. However, the EGF-10 had no statistically significant difference in proliferative effect on hUC-MSCs with the $20 \mu \mathrm{g} / \mathrm{mL}$ aqueous extract of $H$. parva (Figure 2A). This evidence showed that the $20 \mu \mathrm{g} / \mathrm{mL}$ concentration of the aqueous extract is the optimum dose of sea cucumber extract with minimum cytotoxicity. This concentration was chosen for further analysis.

The number of cells treated with the $20 \mu \mathrm{g} / \mathrm{mL}$ concentration of the extract and EGF-10 were increased faster and higher than the control group (Figure 2B). In details, the cell number of the extract treatment group was higher than the control group from day $6(p<0.01)$. Moreover, this result was observed for the EGF-10 treatment group from day $7(p<0.01)$. On the other hand, the $20 \mu \mathrm{g} / \mathrm{mL}$ concentration of aqueous extract of $H$. parva and EGF-10 did not have significant effects on hUC-MSCs viability comparing to the control group during 13 days (Figure $2 \mathrm{C}$ ).

\subsection{Cell cycle assayed did not show differences in proportion of stages}

The cell cycle assay of hUC-MSCs in the three groups showed that although percent of cells in the G2 stage of the extract and EGF-10 was mathematically higher than the control group, but proportions of different 
stages of all groups were not statistically different (Figure 3).

\subsection{Western blot analysis findings}

The hUC-MSCs were treated with the $20 \mu \mathrm{g} / \mathrm{mL}$ concentration of aqueous extract of H. parva or EGF-10, expression of the cyclin D1, cyclin D3, cyclin E, HIF-1a, and TERT were increased comparing with the control group (Figure 4). Moreover, expression of the p21 and PCNA decreased after treating hUC-MSCs with the 20 $\mu \mathrm{g} / \mathrm{mL}$ concentration of aqueous extract of H. parva or EGF-10 comparing with the control group. However, the CDC-2/cdk-1 and ERK1/2 had almost the same expression as the control group. The expression of the cdk-4 was decreased and increased after treatment with the extract and EGF-10, respectively. In addition, the cdk- 6 expression was decreased and increased after cell treatment with the extract and EGF-10, respectively.

\subsection{Six compounds showed better affinity to proteins}

The docking process of each ligand-protein complex resulted in 10 conformations with different binding affinity as a docking score. Among them, the conformation with RMSD $\leq 2 \AA$ and the lowest binding affinity, $\Delta \mathrm{G}[\mathrm{U}$ total in $\mathrm{kcal} / \mathrm{mol}$ was chosen as the best or the most stable one. Table 2 presents $\Delta \mathrm{G}$ corresponding to the best conformations. The binding energies are in the range of -2.5 to $-7.9 \mathrm{Kcal} / \mathrm{mol}$ with mean value of $-4.7 \mathrm{Kcal} / \mathrm{mol}$. The highest $\Delta \mathrm{G}$ was related to the complex of p21 with Decane 4-methyl- and Tridecane. The lowest $\Delta G$ was related to the complex of Cyclin D3 with 3,4-Dihydro-1h-isoquinoline-2-carboxamidine hydrochloride.

Figures S3-S11 shows the 3D plot of the active sites and the 2D plot of interactions of these proteins with mentioned compounds. As observed, different interactions, including hydrogen bonds, which are strong bonds, van der Waals and $\pi-\pi$ interactions play role in the binding of compounds to proteins. According to the result of docking study, the highest affinity to CDK4 was related to 2-Cyclohexen-1-ol, 2-methyl-5-(1methylethenyl)-, (1S)-. The highest affinity to CDK6 was related to 1, 2-benzenedicarboxylic acid, diisooctyl ester and 3,4-Dihydro-1h-isoquinoline-2-carboxamidine hydrochloride. The highest affinity to Cyclin D1 was related to 1, 2-benzenedicarboxylic acid, diisooctyl ester and 3,4-Dihydro-1h-isoquinoline-2-carboxamidine hydrochloride and 8-amino-6-methoxyquinoline. The highest affinity to Cyclin D3 was related to 3,4-Dihydro1h-isoquinoline-2-carboxamidine hydrochloride, Isopinocarveol, E-2, 3-epoxycarane, 2-Cyclohexen-1-ol, 2methyl-5-(1-methylethenyl)-, (1S)-, and Benzene, 2-(butenyl)-5-(1, 1-dimethylethyl)-1, 3-dimethyl-. The highest affinity to Cyclin E was related to 1, 2-benzenedicarboxylic acid, diisooctyl ester and 3,4-Dihydro-1hisoquinoline-2-carboxamidine hydrochloride. The highest affinity to HIF-1a was related to (5E,9E)-6,10Dimethyldodeca-5,9-dien-2-one and 1, 2-benzenedicarboxylic acid, diisooctyl ester. The highest affinity to p21 was related to 3,4-Dihydro-1h-isoquinoline-2-carboxamidine hydrochloride, Azulene and D-glucose, cyclic ethylene mercaptal, pentaacetate and Phenol,2,4-bis(1,1 dimethylethyl)-. The highest affinity to PCNA was related to (5E,9E)-6,10-Dimethyldodeca-5,9-dien-2-one and 3,4-Dihydro-1h-isoquinoline-2-carboxamidine hydrochloride, and Cyclooctaneacetic acid, 2-oxo-. The highest affinity to TERT was related to 1, 2benzenedicarboxylic acid, diisooctyl ester and 3,4-Dihydro-1h-isoquinoline-2-carboxamidine hydrochloride. Therefore, six compounds can be considered as the most effective ones. 


\section{Discussion}

In the present study aqueous extract of $H$. parva induced proliferation of hUC-MSCs same as EGF. Growth factors, including EGF, fibroblast growth factor (FGF), transforming growth factor beta (TGF $\beta$ ), and bone morphogenetic protein (BMP) induce proliferation in multipotent MSCs cells (30). These cytokines play roles in regeneration and development of sea cucumbers (31). Consistent with our findings protein fractions from PBS and acetic acid crude extracts of $H$. scabra body wall increased the growth kinetics of placentaderived MSCs (10). In addition, the pepsin-solubilized collagen extract of Stichopus japonicus enhanced human keratinocyte cell proliferation (12). Water extract of $S$. variegatus induced proliferation activity of spinal astrocytes cell lines (9). Optimum concentration of $S$. chloronotus aqueous extract enhanced wound healing in rat models (11). Therefore, extract of $H$. parva has bioactive compounds for induction of proliferation in hUC-MSCs.

On the other hand, the proportion of the cells at G2 stage after treating with aqueous extract of $H$. parva and EGF were higher than control group. This result indicated that the cells after treatment with both extract and EGF undergoes proliferation and they are in pre-mitosis stage. In line with the current result, previous studies showed that the extracts which induce cell proliferation, increased S and G2 phases and finally mitosis (32). Moreover, the effects of aqueous extract of $H$. parva on proliferation related peptides in hUCMSCs were assessed. Aqueous extract of $H$. parva or EGF upregulated expression of the cyclin D1, cyclin D3, and cyclin E in the hUC-MSCs. Cyclin D protein subfamilies cyclin D1 and cyclin D3 plays an important role in cell proliferation (33). They do this role by activating cdk-4 or cdk-6 (33). Similar to our findings, EGF induces hair follicle-derived MSC proliferation through the EGFR/ERK and AKT pathways associated by upregulation of cyclin D1 expression and stimulation of G1/S transition (34). It is shown that cyclin D3 expressed in cells stimulated by EGF for a G1 phase progression (35). Cyclin E form the CDK2-cyclin E complexes which both promote the G1/S phase progression (36). On the other hand, Aqueous extract of $H$. parva or EGF downregulated expression of the p21 in the hUC-MSCs. The p21 protein is a CDK inhibitor and downregulates proliferation by preventing the transcription of cell cycle-regulated pro-proliferative proteins (37). EGF promotes cell growth by suppressing p21 (38). Therefore, aqueous extract of $H$. parva as same as EGF induced proliferation of hUC-MSCs through upregulation of cyclins subfamilies and suppressing cellular senescence-related protein (Figure 5).

Aqueous extract of $H$. parva or EGF upregulated expression of the TERT in the hUC-MSCs. TERT (telomerase reverse transcriptase) maintains telomere length to enable cells to proliferate (39). TERT mRNA expression increased in the hUC-MSCs treated by EGF (40). TERT expression is high in stem cells during proliferation and reduced upon differentiation (39). EGF activates TERT transcription in cancer cells but not in somatic cells (41). Therefore, aqueous extract of $H$. parva as same as EGF induced proliferation of hUC-MSCs through maintaining telomere length.

Aqueous extract of $H$. parva or EGF increased expression of the HIF-1a in the hUC-MSCs. Hypoxia-inducible factor 1 (HIF-1) has been recognized for its key role in transcriptional control of proliferation (42). The EGF is able to stabilize HIF-a under non-hypoxic conditions (43). Growth factors promotes HIF-a binding to DNA to induce gene transcription in cells (44). Similarly, HIF-1 a contributes to the proliferative response of cells 
to growth factors (45). Therefore, aqueous extract of $H$. parva as same as EGF induced proliferation of hUCMSCs through maintaining telomere length.

After docking analysis of GC-MS-detected bioactive compounds, 13 compounds with the effective proteins in the stem cell proliferation the following compounds showed the highest affinity. 3,4-Dihydro-1hisoquinoline-2-carboxamidine hydrochloride other name is debrisoquine which is an antihypertensive drug (46). Debrisoquine hydrochloride showed the highest affinity to CDK4, CDK6, Cyclin D1, Cyclin D3, Cyclin E, PCNA, and TERT. The most affinity of debrisoquine hydrochloride was calculated with Cyclin D3. Increase of Cyclin D3 was observed after sea cucumber extract exposure. Based on best of our knowledge there is no data that show the effects of Debrisoquine hydrochloride on cell proliferation. Cyclooctaneacetic acid, 2oxo- showed the highest affinity to Cyclin D3, CDK4, and PCNA. The most affinity of debrisoquine hydrochloride was calculated with Cyclin D3. After sea cucumber extract exposure into MSCs, Cyclin D3 increased. Based on best of our knowledge there is no data that show the effects of Cyclooctaneacetic acid, 2-oxo- on cell proliferation. 8-amino-6-methoxyquinoline has antimalarial and antiplasmodial activity effect (47). 8-Quinolinamines analogues did not show any cytotoxicity on cancerous and noncancerous cells (48). However, hematotoxic effect of a metabolite of 8-amino-6-methoxyquinoline on erythrocyte has been reported (49). 8-amino-6-methoxyquinoline showed the highest affinity to Cyclin D1, Cyclin D3, and CDK4. The most affinity of 8-amino-6-methoxyquinoline was calculated with Cyclin D3. There was no data on the effect of this compound on cell growth. Isopinocarveol which has been also known as Pinocarveol has antiviral effect $(50,51)$. It has been reported that trans-pinocarveol has antigenotoxic potential $(52)$.

Pinocarveol showed the highest affinity to Cyclin D3 in our present study. 1, 2-benzenedicarboxylic acid, diisooctyl ester other name is Diisooctyl phthalate which is shown previously in the sea cucumber (15). 1, 2benzenedicarboxylic acid, diisooctyl ester has antioxidant activity (53). Diisooctyl phthalate had fungitoxic effect on six fungi and cytotoxic activity on newborn shrimp (54). Diisooctyl phthalate showed the highest affinity to CDK6, Cyclin D1, Cyclin E, HIF-1a, PCNA, and TERT. The most affinity of Diisooctyl phthalate was calculated with CDK6. Decrease of CDK6 was observed after sea cucumber extract exposure. E-2, 3epoxycarane is a terpenoid. E-2, 3-epoxycarane has anti-aging effects on skin $(55,56)$. E-2, 3-epoxycarane showed the highest affinity to Cyclin D3 in our present study.

\section{Conclusions}

The aqueous extracts of sea cucumber, $H$. parva, same as EGF, were able to induce proliferation in hUCMSCs. The GC-MS detected six effective bioactive compounds in sea cucumber aqueous extract had the property of inducing stem cell proliferation.

\section{Abbreviations}

3D, Three-dimensional

BMP, Bone morphogenetic protein

DMEM, Dulbecco's Modified Eagle's medium 
DMSO, Dimethyl sulfoxide

EGF, Epidermal growth factor

El, Electronionization

FGF, Fibroblast growth factor

FITC, Fluorescein isothiocyanate

GC-MS, Gas chromatography-mass spectrometry

H. parva, Holothuria parva

H. scabra, Holothuria scabra

hUC-MSCs, Human umbilical cord mesenchymal stromal/stem cells

MTT, 3-(4,5-dimethylthiazol-2-yl)-2,5-diphenyltetrazolium bromide

PBS, Phosphate buffer saline

PDB, Protein Database Bank

PE, Phycoerythrin

Pl, propidiumlodide

TGF $\beta$, Transforming growth factor beta

\section{Declarations}

\section{Ethics approval and consent to participate}

This investigation was performed in accordance with relevant guidelines and regulations of the ethical committee of Bushehr University of Medical Sciences (Permission number: IR.BPUMS.REC.1398.091).

\section{Consent for publication}

Not applicable.

\section{Funding}

This work was supported by a grant from Bushehr University of Medical Sciences, grant no. 1271. 


\section{Competing interests}

We wish to confirm that there are no known conflicts of interest associated with this publication and there has been no significant financial support for this work that could have influenced its outcome.

\section{Authors' contributions}

A. T., S. A., R. S. and I. N. conceived and designed the format of the manuscript. P. R., A. K., A. K., N. B., G. M., A. B., H. A., Y. H., A. D., A. B., Z. K. and S. Z. collected the data, and drafted and edited the manuscript. A. T., N. B, G. M., and A. K. computational and statistical analysis. N. B., A. T., A. K., P. R., G. M. and A. K. drew the Figures and Tables. All the authors reviewed the manuscript and all of them contributed to the critical reading and discussion of the manuscript. All authors have read and agreed to the published version of the manuscript.

\section{Acknowledgments}

Not applicable.

\section{Availability of data and material}

The dataset supporting the conclusions of this article are included within the article and its additional files.

\section{References}

1. Xie Q, Liu R, Jiang J, Peng J, Yang C, Zhang W, et al. What is the impact of human umbilical cord mesenchymal stem cell transplantation on clinical treatment? Stem cell research \& therapy. 2020;11(1):1-13.

2. Jo H, Brito S, Kwak BM, Park S, Lee MG, Bin BH. Applications of Mesenchymal Stem Cells in Skin Regeneration and Rejuvenation. Int J Mol Sci. 2021;22(5):2410.

3. Rice P, Orgill D. Assessment and classification of burn injury. Uptodate [internet] Waltham (MA): UpToDate Inc. 2019.

4. Tottoli EM, Dorati R, Genta I, Chiesa E, Pisani S, Conti B. Skin Wound Healing Process and New Emerging Technologies for Skin Wound Care and Regeneration. Pharmaceutics. 2020;12(8):735.

5. Ornelas-González A, Chairez-Cantu K, Ortiz-Martínez M, González-González M, Rito-Palomares M. Stem cell culture media enriched with plant-derived compounds: Cell proliferation enhancement. Journal of Chemical Technology \& Biotechnology. 2021.

6. Ormond DR, Shannon C, Oppenheim J, Zeman R, Das K, Murali R, et al. Stem cell therapy and curcumin synergistically enhance recovery from spinal cord injury. PLoS One. 2014;9(2):e88916. 
7. San Miguel-Ruiz JE, Garcia-Arraras JE. Common cellular events occur during wound healing and organ regeneration in the sea cucumber Holothuria glaberrima. BMC Dev Biol. 2007;7(1):115.

8. Khotimchenko Y. Pharmacological Potential of Sea Cucumbers. Int J Mol Sci. 2018;19(5):1342.

9. Patar A, Jamalullail S, Jaafar H, Abdullah JM. The effect of water extract of sea cucumber Stichopus variegatus on rat spinal astrocytes cell lines. Current Neurobiology. 2012;3(1):11-6.

10. Kornthong N, Saengsuwan J, Duangprom S, Songkoomkrong S, Vivattanasarn T, Suwansa-ard S, et al. The Effect of Sea Cucumber Extract (Holothuria scabra) on the Proliferation of Human Placenta Derived Mesenchymal Stromal Cells. JOURNAL OF THE MEDICAL ASSOCIATION OF THAILAND. 2020;103(3):24.

11. Mazliadiyana M, Nazrun A, Isa N. Optimum dose of sea cucumber (Stichopus chloronotus) extract for wound healing. Med Health. 2017;12(1):83-9.

12. Park SY, Lim HK, Lee S, Hwang HC, Cho SK, Cho M. Pepsin-solubilised collagen (PSC) from Red Sea cucumber (Stichopus japonicus) regulates cell cycle and the fibronectin synthesis in $\mathrm{HaCaT}$ cell migration. Food Chem. 2012;132(1):487-92.

13. Purcell S, Samyn Y, Conand C. Commercially Important Sea Cucumbers of the World. Rome: Food and Agriculture Organization of The United Nations; 2012.

14. Samyn Y, Vandenspiegel D, Massin C. Taxonomie des holothuries des Comores2006.

15. Keshavarz M, Shamsizadeh F, Tavakoli A, Baghban N, Khoradmehr A, Kameli A, et al. Chemical compositions and experimental and computational modeling activity of sea cucumber Holothuria parva ethanolic extract against herpes simplex virus type 1. Biomed Pharmacother. 2021;141:111936.

16. Mohebbi G, Nabipour I, Vazirizadeh A, Vatanpour H, Farrokhnia M, Maryamabadi A, et al. Acetylcholinesterase inhibitory activity of a neurosteroidal alkaloid from the upside-down jellyfish Cassiopea andromeda venom. Revista Brasileira de Farmacognosia. 2018;28(5):568-74.

17. Rezaeian L, Hosseini SE, Dianatpour M, Edalatmanesh MA, Tanideh N, Mogheiseh A, et al. Intrauterine xenotransplantation of human Wharton jelly-derived mesenchymal stem cells into the liver of rabbit fetuses: A preliminary study for in vivo expression of the human liver genes. Iran J Basic Med Sci. 2018;21(1):89-96.

18. Kadam S, Govindasamy V, Bhonde R. Generation of functional islets from human umbilical cord and placenta derived mesenchymal stem cells. Somatic Stem Cells: Springer; 2012. p. 291-313.

19. Bazoobandi S, Tanideh N, Rahmanifar F, Zare S, Koohi-Hosseinabadi O, Razeghian-Jahromi I, et al. Preventive Effects of Intrauterine Injection of Bone Marrow-Derived Mesenchymal Stromal CellConditioned Media on Uterine Fibrosis Immediately after Endometrial Curettage in Rabbit. Stem Cells Int. 2020;2020:8849537.

20. Zeng HL, Zhong Q, Qin YL, Bu QQ, Han XA, Jia HT, et al. Hypoxia-mimetic agents inhibit proliferation and alter the morphology of human umbilical cord-derived mesenchymal stem cells. BMC Cell Biol. 2011;12(1):32.

21. Tamadon A, Mehrabani D, Zarezadeh Y, Rahmanifar F, Dianatpour M, Zare S. Caprine Endometrial Mesenchymal Stromal Stem Cell: Multilineage Potential, Characterization, and Growth Kinetics in 
Breeding and Anestrous Stages. Vet Med Int. 2017;2017:5052801.

22. Zhang H, Li ZL, Yang F, Zhang Q, Su XZ, Li J, et al. Radial shockwave treatment promotes human mesenchymal stem cell self-renewal and enhances cartilage healing. Stem Cell Res Ther. 2018;9(1):54.

23. Yip WK, Cheenpracha S, Chang LC, Ho CC, Seow HF. Anti-proliferative and anti-invasive properties of a purified fraction from Streptomyces sp. H7372. Int J Oncol. 2010;37(5):1229-41.

24. Terekhova EA, Stepicheva NA, Pshenichnikova AB, Shvets VI. [Stearic acid methyl ether: a new extracellular metabolite of the obligate methylotrophic bacterium Methylophilus quaylei]. Prikladnaia biokhimiia i mikrobiologiia. 2010;46(2):180-6.

25. Othman AR, Abdullah N, Ahmad S, Ismail IS, Zakaria MP. Elucidation of in-vitro anti-inflammatory bioactive compounds isolated from Jatropha curcas L. plant root. BMC complementary and alternative medicine. 2015;15:11.

26. Chen PY, Wu CY, Clemons GA, Citadin CT, Couto ESA, Possoit HE, et al. Stearic acid methyl ester affords neuroprotection and improves functional outcomes after cardiac arrest. Prostaglandins, leukotrienes, and essential fatty acids. 2020;159:102138.

27. Panagiotopoulos A, Tseliou M, Karakasiliotis I, Kotzampasi DM, Daskalakis V, Kesesidis N, et al. pcymene impairs SARS-CoV-2 and Influenza A (H1N1) viral replication: In silico predicted interaction with SARS-CoV-2 nucleocapsid protein and H1N1 nucleoprotein. Pharmacol Res Perspect. 2021;9(4):e00798.

28. Formiga RO, Alves Junior EB, Vasconcelos RC, Araujo AA, de Carvalho TG, de Araujo Junior RF, et al. Effect of p-cymene and rosmarinic acid on gastric ulcer healing - Involvement of multiple endogenous curative mechanisms. Phytomedicine: international journal of phytotherapy and phytopharmacology. 2021;86:153497.

29. Hassan SMH, Ray P, Hossain R, Islam MT, Salehi B, Martins N, et al. p-Cymene metallo-derivatives: An overview on anticancer activity. Cellular and molecular biology (Noisy-le-Grand, France). 2020;66(4):28-32.

30. Rodrigues M, Griffith LG, Wells A. Growth factor regulation of proliferation and survival of multipotential stromal cells. Stem Cell Res Ther. 2010;1(4):32.

31. Sun L, Chen M, Yang H, Wang T, Liu B, Shu C, et al. Large scale gene expression profiling during intestine and body wall regeneration in the sea cucumber Apostichopus japonicus. Comp Biochem Physiol Part D Genomics Proteomics. 2011;6(2):195-205.

32. Chafouleas JG, Bolton WE, Hidaka H, Boyd III AE, Means AR. Calmodulin and the cell cycle: involvement in regulation of cell-cycle progression. Cell. 1982;28(1):41-50.

33. Pestell RG. New roles of cyclin D1. Am J Pathol. 2013;183(1):3-9.

34. Bai T, Liu F, Zou F, Zhao G, Jiang Y, Liu L, et al. Epidermal growth factor induces proliferation of hair follicle-derived mesenchymal stem cells through epidermal growth factor receptor-mediated activation of ERK and AKT signaling pathways associated with upregulation of cyclin D1 and downregulation of p16. Stem cells and development. 2017;26(2):113-22. 
35. Depoortere F, Van Keymeulen A, Lukas J, Costagliola S, Bartkova J, Dumont JE, et al. A requirement for cyclin D3-cyclin-dependent kinase (cdk)-4 assembly in the cyclic adenosine monophosphate-dependent proliferation of thyrocytes. J Cell Biol. 1998;140(6):1427-39.

36. Shen H, Zhou E, Wei X, Fu Z, Niu C, Li Y, et al. High density lipoprotein promotes proliferation of adipose-derived stem cells via S1P1 receptor and Akt, ERK1/2 signal pathways. Stem Cell Res Ther. 2015;6(1):95.

37. Arthur LM, Heber-Katz E. The role of p21 in regulating mammalian regeneration. Stem Cell Res Ther. 2011;2(3):30.

38. Alexander PB, Yuan L, Yang P, Sun T, Chen R, Xiang H, et al. EGF promotes mammalian cell growth by suppressing cellular senescence. Cell research. 2015;25(1):135-8.

39. Mattson MP, Zhang P, Fu W. Roles for TERT and telomerase in cell differentiation and apoptosis. Madame Curie Bioscience Database [Internet]: Landes Bioscience; 2013.

40. Salehinejad P, Alitheen NB, Mandegary A, Nematollahi-Mahani SN, Janzamin E. Effect of EGF and FGF on the expansion properties of human umbilical cord mesenchymal cells. In Vitro Cell Dev Biol Anim. 2013;49(7):515-23.

41. Bermudez Y, Yang H, Cheng JQ, Kruk PA. Pyk2/ERK $1 / 2$ mediate Sp1-and c-Myc-dependent induction of telomerase activity by epidermal growth factor. Growth Factors. 2008;26(1):1-11.

42. Tekin D, Dursun AD, Xi L. Hypoxia inducible factor 1 (HIF-1) and cardioprotection. Acta Pharmacol Sin. 2010;31(9):1085-94.

43. Sun J, Shen H, Shao L, Teng X, Chen Y, Liu X, et al. HIF-1alpha overexpression in mesenchymal stem cell-derived exosomes mediates cardioprotection in myocardial infarction by enhanced angiogenesis. Stem Cell Res Ther. 2020;11(1):373.

44. Richard DE, Berra E, Pouyssegur J. Nonhypoxic pathway mediates the induction of hypoxia-inducible factor 1alpha in vascular smooth muscle cells. J Biol Chem. 2000;275(35):26765-71.

45. Schultz K, Fanburg BL, Beasley D. Hypoxia and hypoxia-inducible factor-1alpha promote growth factorinduced proliferation of human vascular smooth muscle cells. Am J Physiol Heart Circ Physiol. 2006;290(6):H2528-34.

46. Idle JR, Mahgoub A, Angelo MM, Dring LG, Lancaster R, Smith RL. The metabolism of [14C]debrisoquine in man. British journal of clinical pharmacology. 1979;7(3):257-66.

47. Hochegger P, Dolensky J, Seebacher W, Saf R, Kaiser M, Maser P, et al. 8-Amino-6-MethoxyquinolineTetrazole Hybrids: Impact of Linkers on Antiplasmodial Activity. Molecules (Basel, Switzerland). 2021;26(18):5530.

48. Jain M, Reddy CRP, Halder M, Singh S, Kumar R, Wasudeo SG, et al. Synthesis and biological evaluation of 8-quinolinamines and their amino acid conjugates as broad-spectrum anti-infectives. ACS omega. 2018;3(3):3060-75.

49. Bolchoz LJ, Budinsky RA, McMillan DC, Jollow DJ. Primaquine-induced hemolytic anemia: formation and hemotoxicity of the arylhydroxylamine metabolite 6-methoxy-8-hydroxylaminoquinoline. The Journal of pharmacology and experimental therapeutics. 2001;297(2):509-15. 
50. Yadalam PK, Varatharajan K, Rajapandian K, Chopra P, Arumuganainar D, Nagarathnam T, et al. Antiviral Essential Oil Components Against SARS-CoV-2 in Pre-procedural Mouth Rinses for Dental Settings During COVID-19: A Computational Study. Front Chem. 2021;9(86):642026.

51. El Yaagoubi M, Ortiz S, Mechqoq H, Cavaleiro C, Lecso-Bornet M, Rodrigues MJ, et al. Chemical Composition, Antibacterial Screening and Cytotoxic Activity of Chiliadenus antiatlanticus (Asteraceae) Essential Oil. Chemistry \& biodiversity. 2021;18(6):e2100115.

52. Drosopoulou E, Vlastos D, Efthimiou I, Kyrizaki P, Tsamadou S, Anagnostopoulou M, et al. In vitro and in vivo evaluation of the genotoxic and antigenotoxic potential of the major Chios mastic water constituents. Sci Rep. 2018;8(1):12200.

53. Li M, Zhou L, Yang D, Li T, Li W. Biochemical composition and antioxidant capacity of extracts from Podophyllum hexandrum rhizome. BMC complementary and alternative medicine. 2012;12:263.

54. Shafiqur Rahman MD, Anwar MN. Fungitoxic and cytotoxic activity of a novel compound 1,2benzenedicarboxylic acid, diisooctyl ester of Plumbago zeylanica linn. Asian Journal of Microbiology, Biotechnology and Environmental Sciences. 2006;8:461-4.

55. Vertuani S, Beghelli E, Scalambra E, Malisardi G, Copetti S, Toso RD, et al. Activity and stability studies of verbascoside, a novel antioxidant, in dermo-cosmetic and pharmaceutical topical formulations. Molecules (Basel, Switzerland). 2011;16(8):7068-80.

56. Young E, Godwin J. Assessing Olive, Palm Kernel, and Groundnut Oils for their Dermatologically-Active Agents. 2019.

57. Chen S, Liu J, Gong H, Yang D. [Identification and antibacterial activity of secondary metabolites from Taxus endophytic fungus]. Sheng Wu Gong Cheng Xue Bao. 2009;25(3):368-74.

58. Hakozaki T, Laughlin T, Zhao S, Wang J, Deng D, Jewell-Motz E, et al. A regulator of ubiquitinproteasome activity, 2-hexyldecanol, suppresses melanin synthesis and the appearance of facial hyperpigmented spots. Br J Dermatol. 2013;169 Suppl 2:39-44.

59. Shirani M, Samimi A, Kalantari H, Madani M, Kord Zanganeh A. Chemical composition and antifungal effect of hydroalcoholic extract of Allium tripedale (Tvautv.) against Candida species. Curr Med Mycol. 2017;3(1):6-12.

60. Figueiredo CR, Matsuo AL, Massaoka MH, Girola N, Azevedo RA, Rabaca AN, et al. Antitumor activity of kielmeyera coriacea leaf constituents in experimental melanoma, tested in vitro and in vivo in syngeneic mice. Adv Pharm Bull. 2014;4(Suppl 1):429-36.

61. Vambe M, Naidoo D, Aremu AO, Finnie JF, Van Staden J. Bioassay-guided purification, GC-MS characterization and quantification of phyto-components in an antibacterial extract of Searsia lancea leaves. Natural product research. 2019:1-5.

62. Lim CS, Wong WF, Rosli R, Ng KP, Seow HF, Chong PP. 2-dodecanol (decyl methyl carbinol) inhibits hyphal formation and SIR2 expression in C. albicans. Journal of basic microbiology. 2009;49(6):57983.

63. Rajendran BK, Xavier Suresh M, Bhaskaran SP, Harshitha Y, Gaur U, Kwok HF. Pharmacoinformatic Approach to Explore the Antidote Potential of Phytochemicals on Bungarotoxin from Indian Krait, Bungarus caeruleus. Computational and structural biotechnology journal. 2018;16:450-61. 
64. Witkowska-Banaszczak E, Długaszewska J. Essential oils and hydrophilic extracts from the leaves and flowers of Succisa pratensis Moench. and their biological activity. Journal of Pharmacy and Pharmacology. 2017;69(11):1531-9.

65. Doukas PH, Speaker TJ, Thompson RS. Azulene analogs of pharmacological agents III: acute toxicity and local anesthetic activity of azulylamides and azulenecarboxamides. Journal of pharmaceutical sciences. 1975;64(1):158-61.

66. Chen $\mathrm{CH}$, Lee O, Yao CN, Chuang MY, Chang YL, Chang MH, et al. Novel azulene-based derivatives as potent multi-receptor tyrosine kinase inhibitors. Bioorganic \& medicinal chemistry letters. 2010;20(20):6129-32.

67. Aoki S, Ohta K, Matsumoto K, Sakai H, Abe M, Miura M, et al. An emulsion of sulfoquinovosylacylglycerol with long-chain alkanes increases its permeability to tumor cells. The Journal of membrane biology. 2006;213(1):11-8.

68. Dhouibi R, Moalla D, Ksouda K, Ben Salem M, Hammami S, Sahnoun Z, et al. Screening of analgesic activity of Tunisian Urtica dioica and analysis of its major bioactive compounds by GCMS. Archives of physiology and biochemistry. 2018;124(4):335-43.

69. Thabet AA, Youssef FS, El-Shazly M, AN BS. GC-MS and GC-FID analyses of the volatile constituents of Brachychiton rupestris and Brachychiton discolor, their biological activities and their differentiation using multivariate data analysis. Natural product research. 2020;34(4):590-4.

70. Herman S, Kny A, Schorn C, Pfatschbacher J, Niederreiter B, Herrmann M, et al. Cell death and cytokine production induced by autoimmunogenic hydrocarbon oils. Autoimmunity. 2012;45(8):602-11.

71. George JD, Price CJ, Marr MC, Myers CB, Schwetz BA, Heindel JJ. Evaluation of the developmental toxicity of methacrylamide and N,N'-methylenebisacrylamide in Swiss mice. Toxicological sciences: an official journal of the Society of Toxicology. 1998;46(1):124-33.

72. Mozaffarian D, Cao H, King IB, Lemaitre RN, Song X, Siscovick DS, et al. Circulating palmitoleic acid and risk of metabolic abnormalities and new-onset diabetes. Am J Clin Nutr. 2010;92(6):1350-8.

73. Zhang L, Lv J, Chen C, Wang X. Roles of acyl-CoA synthetase long-chain family member 5 and colony stimulating factor 2 in inhibition of palmitic or stearic acids in lung cancer cell proliferation and metabolism. Cell biology and toxicology. 2021;37(1):15-34.

74. Bi C, Zhang T, Li Y, Zhao H, Zhang P, Wang Y, et al. A Proteomics- and Metabolomics-Based Study Revealed That Disorder of Palmitic Acid Metabolism by Aconitine Induces Cardiac Injury. Chemical research in toxicology. 2020;33(12):3031-40.

75. Sanchez-Alegria K, Bastian-Eugenio CE, Vaca L, Arias C. Palmitic acid induces insulin resistance by a mechanism associated with energy metabolism and calcium entry in neuronal cells. FASEB journal: official publication of the Federation of American Societies for Experimental Biology. 2021;35(7):e21712.

76. Galindo-Hernandez O, Leija-Montoya AG, Romero-Garcia T, Vazquez-Jimenez JG. Palmitic acid decreases cell migration by increasing RGS2 expression and decreasing SERCA expression. Genetics and molecular biology. 2021;44(1):e20200279. 
77. Korbecki J, Bajdak-Rusinek K. The effect of palmitic acid on inflammatory response in macrophages: an overview of molecular mechanisms. Inflammation research: official journal of the European Histamine Research Society [et al]. 2019;68(11):915-32.

78. Marrez DA, Naguib MM, Sultan YY, Higazy AM. Antimicrobial and anticancer activities of Scenedesmus obliquus metabolites. Heliyon. 2019;5(3):e01404.

79. Rajkumar S, Jebanesan A. Mosquitocidal activities of octacosane from Moschosma polystachyum Linn (lamiaceae). Journal of ethnopharmacology. 2004;90(1):87-9.

80. Jing LL, He L, Fan PC, Jia ZP, Ma HP. [Chemical Constituents with Anti-hypoxia Activity from Saussurea involucrata]. Zhong yao cai $=$ Zhongyaocai $=$ Journal of Chinese medicinal materials. 2015;38(1):8992.

81. Figueiredo CR, Matsuo AL, Pereira FV, Rabaca AN, Farias CF, Girola N, et al. Pyrostegia venusta heptane extract containing saturated aliphatic hydrocarbons induces apoptosis on B16F10-Nex2 melanoma cells and displays antitumor activity in vivo. Pharmacogn Mag. 2014;10(Suppl 2):S363-76.

82. Tátrai E, Ungváry G, Cseh IR, Mányai S, Szeberényi S, Molnár J, et al., editors. The Effect of Long-term Inhalation of Ortho-Xylene on the Liver. Industrial and Environmental Xenobiotics; 1981 1981//; Berlin, Heidelberg: Springer Berlin Heidelberg.

83. Sarma SN, Kim YJ, Song M, Ryu JC. Induction of apoptosis in human leukemia cells through the production of reactive oxygen species and activation of HMOX1 and Noxa by benzene, toluene, and oxylene. Toxicology. 2011;280(3):109-17.

84. Varsha KK, Devendra L, Shilpa G, Priya S, Pandey A, Nampoothiri KM. 2,4-Di-tert-butyl phenol as the antifungal, antioxidant bioactive purified from a newly isolated Lactococcus sp. International journal of food microbiology. 2015;211:44-50.

85. Zhao F, Wang P, Lucardi RD, Su Z, Li S. Natural Sources and Bioactivities of 2,4-Di-Tert-Butylphenol and Its Analogs. Toxins (Basel). 2020;12(1):35.

86. Chathuranga K, Weerawardhana A, Dodantenna N, Ranathunga L, Cho WK, Ma JY, et al. Inhibitory Effect of Sargassum fusiforme and Its Components on Replication of Respiratory Syncytial Virus In Vitro and In Vivo. Viruses. 2021;13(4).

87. Paudel MR, Chand MB, Pant B, Pant B. Assessment of Antioxidant and Cytotoxic Activities of Extracts of Dendrobium crepidatum. Biomolecules. 2019;9(9):478.

88. Uddin SJ, Grice D, Tiralongo E. Evaluation of cytotoxic activity of patriscabratine, tetracosane and various flavonoids isolated from the Bangladeshi medicinal plant Acrostichum aureum. Pharmaceutical biology. 2012;50(10):1276-80.

89. Muhammad F, Monteiro-Riviere NA, Riviere JE. Comparative in vivo toxicity of topical JP-8 jet fuel and its individual hydrocarbon components: identification of tridecane and tetradecane as key constituents responsible for dermal irritation. Toxicol Pathol. 2005;33(2):258-66.

90. Sharma R, Locke BR. Jet fuel toxicity: skin damage measured by $900-\mathrm{MHz}$ MRI skin microscopy and visualization by 3D MR image processing. Magnetic resonance imaging. 2010;28(7):1030-48. 
91. Zazula R, Moravec M, Pehal F, Nejtek T, Protus M, Muller M. Myristic Acid Serum Levels and Their Significance for Diagnosis of Systemic Inflammatory Response, Sepsis, and Bacteraemia. Journal of personalized medicine. 2021;11(4).

92. Khalil ASM, Giribabu N, Yelumalai S, Shahzad H, Kilari EK, Salleh N. Myristic acid defends against testicular oxidative stress, inflammation, apoptosis: Restoration of spermatogenesis, steroidogenesis in diabetic rats. Life sciences. 2021;278:119605.

93. Kim YG, Lee JH, Park S, Kim S, Lee J. Inhibition of polymicrobial biofilm formation by saw palmetto oil, lauric acid and myristic acid. Microbial biotechnology. 2021.

94. Singh S, Singh J. Percutaneous absorption, biophysical, and macroscopic barrier properties of porcine skin exposed to major components of JP-8 jet fuel. Environmental toxicology and pharmacology. 2003;14(1-2):77-85.

95. Singh S, Singh J. Dermal toxicity and microscopic alterations by JP-8 jet fuel components in vivo in rabbit. Environmental toxicology and pharmacology. 2004;16(3):153-61.

96. Choi D, Kang W, Park T. Anti-Allergic and Anti-Inflammatory Effects of Undecane on Mast Cells and Keratinocytes. Molecules (Basel, Switzerland). 2020;25(7).

97. Nagella P, Ahmad A, Kim SJ, Chung IM. Chemical composition, antioxidant activity and larvicidal effects of essential oil from leaves of Apium graveolens. Immunopharmacology and immunotoxicology. 2012;34(2):205-9.

\section{Tables}

\section{Table 1}

GC-MS compounds in aqueous extract of sea cucumber (Holothuria parva) based on PubChem database 


\begin{tabular}{|c|c|c|c|c|}
\hline Compounds & Formula & Effects & $\begin{array}{l}\mathrm{MW} \\
(\mathrm{g} / \mathrm{mol})\end{array}$ & References \\
\hline $\begin{array}{l}\text { 1, 2-benzenedicarboxylic } \\
\text { acid, diisooctyl ester }\end{array}$ & $\mathrm{C}_{24} \mathrm{H}_{38} \mathrm{O}_{4}$ & Anti-microbial & 390.6 & (57) \\
\hline $\begin{array}{l}\text { 10-methyl-e-11-tridecen-1-ol } \\
\text { propionate }\end{array}$ & $\mathrm{C}_{17} \mathrm{H}_{32} \mathrm{O}_{2}$ & ND & 268.4 & ND \\
\hline 1-decanol, 2-hexyl- & $\mathrm{C}_{16} \mathrm{H}_{34} \mathrm{O}$ & Proteolytic activity & 242.44 & (58) \\
\hline 1-decanol, 2-methyl- & $\mathrm{C}_{11} \mathrm{H}_{24} \mathrm{O}$ & ND & 172.31 & ND \\
\hline 1-decen-4-yne, 2-nitro- & $\mathrm{C}_{10} \mathrm{H}_{15} \mathrm{NO}_{2}$ & ND & 181.23 & ND \\
\hline \multirow[t]{2}{*}{ 1-eicosanol } & $\mathrm{C}_{20} \mathrm{H}_{42} \mathrm{O}$ & Anti-microbial & 298.5 & $(59,60)$ \\
\hline & & Anti-cancer & & \\
\hline 1-heptadecanol & $\mathrm{C}_{17} \mathrm{H}_{36} \mathrm{O}$ & ND & 256.5 & ND \\
\hline 1-nonadecanol & $\mathrm{C}_{19} \mathrm{H}_{40} \mathrm{O}$ & Anti-microbial & 284.5 & (61) \\
\hline 1-octanol 2-butyl- & $\mathrm{C}_{12} \mathrm{H}_{26} \mathrm{O}$ & ND & 186.33 & ND \\
\hline $\begin{array}{l}\text { 3,4-Dihydro-1h-isoquinoline- } \\
\text { 2-carboxamidine } \\
\text { hydrochloride }\end{array}$ & $\mathrm{C}_{10} \mathrm{H}_{13} \mathrm{~N}_{3}$ & Anti-hypertensive & 175.23 & (46) \\
\hline $\begin{array}{l}\text { 2-(prop-2- } \\
\text { enoyloxy)tetradecane }\end{array}$ & $\mathrm{C}_{17} \mathrm{H}_{32} \mathrm{O}_{2}$ & ND & 268.4 & ND \\
\hline $\begin{array}{l}\text { 2-azido-2,4,4,6,6- } \\
\text { pentamethylheptane }\end{array}$ & $\mathrm{C}_{12} \mathrm{H}_{25} \mathrm{~N}_{3}$ & ND & 211.35 & ND \\
\hline $\begin{array}{l}\text { 2-cyclohexane-1-ol,2-methyl- } \\
\text { 5-(1-methylethenyl) }\end{array}$ & $\mathrm{C}_{10} \mathrm{H}_{16} \mathrm{O}$ & ND & 152.23 & ND \\
\hline \multirow[t]{2}{*}{ 2-dodecanol } & $\mathrm{C}_{12} \mathrm{H}_{26} \mathrm{O}$ & Anti-microbial & 186.33 & $(62,63)$ \\
\hline & & Anti-dotes for bungarotoxin & & \\
\hline \multirow[t]{2}{*}{ 2-hexyl-1-octanol } & $\mathrm{C}_{14} \mathrm{H}_{30} \mathrm{O}$ & Anti-microbial & 214.39 & (64) \\
\hline & & Anti-oxidant & & \\
\hline $\begin{array}{l}\text { 3-hexadecyloxycarbonyl-5-(2- } \\
\text { hydroxyethyl)-4- } \\
\text { methylimidazolium ion }\end{array}$ & $\mathrm{C}_{24} \mathrm{H}_{45} \mathrm{~N}_{2} \mathrm{O}_{3}^{+}$ & ND & 409.6 & ND \\
\hline $\begin{array}{l}\text { 5, 9-dodecadien-2-one, 6, 10- } \\
\text { dimethyl-, (e, e))- }\end{array}$ & $\mathrm{C}_{14} \mathrm{H}_{24} \mathrm{O}$ & ND & 208.34 & ND \\
\hline 8-amino-6-methoxyquinoline & $\mathrm{C}_{10} \mathrm{H}_{10} \mathrm{~N}_{2} \mathrm{O}$ & Hemotoxic & 174.2 & (49) \\
\hline $\begin{array}{l}\text { Octadecanoic acid, methyl } \\
\text { ester }\end{array}$ & $\mathrm{C}_{19} \mathrm{H}_{38} \mathrm{O}_{2}$ & Growth stimulator & 298.5 & $(24-26)$ \\
\hline
\end{tabular}


Anti-inflammatory

Inhibit the detrimental

effects of cerebral ischemia

Azulene

$\mathrm{C}_{10} \mathrm{H}_{8}$

Cytotoxic

128.17

$(65,66)$

Tyrosine kinase inhibitors

Benzene, 1-methyl-4-(1-

methylethenyl)-

Anti-ulcer

134.22

Gastric healing activities

Anti-viral

Anti-cancer

Benzene, 2-(butenyl)-5-(1, 1-

dimethylethyl)-1, 3-dimethyl-

$\mathrm{C}_{16} \mathrm{H}_{24} \quad$ ND

$216.36 \quad N D$

Cyclooctaneacetic acid, 2-

$\mathrm{C}_{10} \mathrm{H}_{16} \mathrm{O}_{3}$

ND

$184.23 \quad N D$

OxO-

Decane

$\mathrm{C}_{10} \mathrm{H}_{22}$

Anti-cancer

142.28

(67)

2,3,5,8-tetramethyldecane

$\mathrm{C}_{14} \mathrm{H}_{30}$

ND

198.39 ND

Decane 4-methyl-

$\mathrm{C}_{11} \mathrm{H}_{24}$

ND

$156.31 \quad$ ND

D-glucose, cyclic ethylene

mercaptal, pentaacetate

$\mathrm{C}_{18} \mathrm{H}_{26} \mathrm{O}_{10} \mathrm{~S}_{2} \quad \mathrm{ND}$

$466.5 \quad N D$

Dodecanal

$\mathrm{C}_{12} \mathrm{H}_{24} \mathrm{O}$

ND

184.32 ND

2,6,11-trimethyldodecane

$\mathrm{C}_{15} \mathrm{H}_{32}$

Analgesic activity

212.41

(68)

E-2, 3-epoxycarane

$\mathrm{C}_{10} \mathrm{H}_{16} \mathrm{O}$

ND

$152.23 \quad N D$

Eicosane

$\mathrm{C}_{20} \mathrm{H}_{42}$

ND

282.5

ND

Heptacosane

$\mathrm{C}_{27} \mathrm{H}_{56}$

Cytotoxic

380.7

$(64,69)$

Anti-microbial

5-ethyl-2,2,3-

trimethylheptane

Hexadecane

$\mathrm{C}_{16} \mathrm{H}_{34}$

Cytotoxic

226.44

(70)

Isopinocarveol

$\mathrm{C}_{10} \mathrm{H}_{16} \mathrm{O}$

Anti-viral

152.23

$(50,51)$

Anti-microbial

Methoxyacetic acid, 2-

tetradecyl ester

Methoxyacetic acid, 3-

tridecyl ester

$\mathrm{C}_{17} \mathrm{H}_{34} \mathrm{O}_{3} \quad \mathrm{ND}$

$286.4 \quad N D$

ND

272.42

ND

Page 22/32 


\begin{tabular}{|c|c|c|c|c|}
\hline $\begin{array}{l}\text { Methoxyacetic acid, } \\
\text { pentadecyl ester }\end{array}$ & $\mathrm{C}_{18} \mathrm{H}_{36} \mathrm{O}_{3}$ & ND & 300.5 & ND \\
\hline $\begin{array}{l}\text { Methyl 3- } \\
\text { hydroxytetradecanoate }\end{array}$ & $\mathrm{C}_{15} \mathrm{H}_{30} \mathrm{O}_{3}$ & ND & 258.4 & ND \\
\hline N,n'-methylenebisacrylamide & $\mathrm{C}_{7} \mathrm{H}_{10} \mathrm{~N}_{2} \mathrm{O}_{2}$ & $\begin{array}{l}\text { Adverse maternal and } \\
\text { developmental effects }\end{array}$ & 154.17 & $(71)$ \\
\hline \multirow[t]{6}{*}{ N-hexadecanoic acid } & \multirow[t]{6}{*}{$\mathrm{C}_{16} \mathrm{H}_{32} \mathrm{O}_{2}$} & Insulin resistance & \multirow[t]{6}{*}{256.42} & \multirow[t]{6}{*}{$(72-77)$} \\
\hline & & Anti-proliferative & & \\
\hline & & Inhibitory effect on cells & & \\
\hline & & $\begin{array}{l}\text { Inhibited activation of the } \\
\text { NLR signaling pathway }\end{array}$ & & \\
\hline & & Reduces cell migration & & \\
\hline & & Inflammatory responses & & \\
\hline \multirow[t]{2}{*}{ Nonadecane } & \multirow[t]{2}{*}{$\mathrm{C}_{19} \mathrm{H}_{40}$} & Anti-microbial & \multirow[t]{2}{*}{268.5} & \multirow[t]{2}{*}{$(78)$} \\
\hline & & Anti-cancer & & \\
\hline \multirow[t]{3}{*}{ Octacosane } & \multirow[t]{3}{*}{$\mathrm{C}_{28} \mathrm{H}_{58}$} & Mosquitocidal activities & \multirow[t]{3}{*}{394.8} & \multirow[t]{3}{*}{$(79-81)$} \\
\hline & & $\begin{array}{l}\text { Prolong the survival time of } \\
\text { hypoxic mice }\end{array}$ & & \\
\hline & & Cytotoxic & & \\
\hline \multirow[t]{2}{*}{ O-xylene } & \multirow[t]{2}{*}{$\mathrm{C}_{8} \mathrm{H}_{10}$} & Poisoning (liver disease) & \multirow[t]{2}{*}{106.16} & \multirow[t]{2}{*}{$(82,83)$} \\
\hline & & Apoptosis induction & & \\
\hline $\begin{array}{l}\text { Pentadecanoic acid, 14- } \\
\text { methyl-, methyl ester }\end{array}$ & $\mathrm{C}_{17} \mathrm{H}_{34} \mathrm{O}_{2}$ & ND & 270.5 & ND \\
\hline Pentanoic acid, octyl ester & $\mathrm{C}_{13} \mathrm{H}_{26} \mathrm{O}_{2}$ & ND & 214.34 & ND \\
\hline \multirow{5}{*}{$\begin{array}{l}\text { Phenol,2,4- } \\
\text { bis(1,1 dimethylethyl)- }\end{array}$} & \multirow[t]{5}{*}{$\mathrm{C}_{14} \mathrm{H}_{22} \mathrm{O}$} & Anti-fungal & \multirow[t]{5}{*}{206.32} & \multirow[t]{5}{*}{$(84,85)$} \\
\hline & & Cytotoxic & & \\
\hline & & Anti-oxidant & & \\
\hline & & Anti-microbial & & \\
\hline & & Anti-viral & & \\
\hline $\begin{array}{l}\text { Sulfurous acid, 2-ethylhexyl } \\
\text { nonyl ester }\end{array}$ & $\mathrm{C}_{17} \mathrm{H}_{36} \mathrm{O}_{3} \mathrm{~S}$ & ND & 320.5 & ND \\
\hline \multirow[t]{2}{*}{ Tetracosane } & \multirow[t]{2}{*}{$\mathrm{C}_{24} \mathrm{H}_{50}$} & Anti-viral & \multirow[t]{2}{*}{338.7} & \multirow[t]{2}{*}{$(86-88)$} \\
\hline & & Cytotoxic & & \\
\hline
\end{tabular}




\begin{tabular}{|c|c|c|c|c|}
\hline Tetradecane & $\mathrm{C}_{14} \mathrm{H}_{30}$ & $\begin{array}{l}\text { Erythema } \\
\text { Cytotoxic }\end{array}$ & 198.39 & $(89,90)$ \\
\hline Tetradecanoic acid & $\mathrm{C}_{14} \mathrm{H}_{28} \mathrm{O}_{2}$ & $\begin{array}{l}\text { Marker of severe } \\
\text { inflammation and sepsis } \\
\text { Bacteraemia marker } \\
\text { Anti-apoptosis } \\
\text { Anti-biofilm activity }\end{array}$ & 228.37 & $(91-93)$ \\
\hline Tridecane & $\mathrm{C}_{13} \mathrm{H}_{28}$ & $\begin{array}{l}\text { Systemic toxicity } \\
\text { Transepidermal water loss }\end{array}$ & 184.36 & $(94,95)$ \\
\hline Undecane & $\mathrm{C}_{11} \mathrm{H}_{24}$ & $\begin{array}{l}\text { Anti-allergic } \\
\text { Anti-inflammatory } \\
\text { Inhibited degranulation and } \\
\text { the secretion of histamine } \\
\text { and tumor necrosis factor a } \\
\text { (TNF-a) }\end{array}$ & 156.31 & (96) \\
\hline Z-10-tetradecen-1-ol acetate & $\mathrm{C}_{16} \mathrm{H}_{30} \mathrm{O}_{2}$ & Anti-oxidant & 254.41 & (97) \\
\hline
\end{tabular}

\section{Table 2}

The values of binding affinity $(\mathrm{Kcal} / \mathrm{mol})$ of ligands to receptors 


\begin{tabular}{|c|c|c|c|c|c|c|c|c|c|}
\hline Compounds & CDK4 & CDK6 & $\begin{array}{l}\text { Cyclin } \\
\text { D1 }\end{array}$ & $\begin{array}{l}\text { Cyclin } \\
\text { D3 }\end{array}$ & $\begin{array}{l}\text { Cyclin } \\
\text { E }\end{array}$ & $\begin{array}{l}\text { HIF- } \\
1 \mathrm{a}\end{array}$ & p21 & PCNA & TERT \\
\hline $\begin{array}{l}(5 \mathrm{E}, 9 \mathrm{E})-6,10- \\
\text { Dimethyldodeca-5,9- } \\
\text { dien-2-one }\end{array}$ & -6.3 & -5.1 & -5.4 & -4.4 & -5.9 & -5.8 & -3.6 & -6 & -5.4 \\
\hline $\begin{array}{l}\text { 1, 2- } \\
\text { benzenedicarboxylic } \\
\text { acid, diisooctyl ester }\end{array}$ & -5.2 & -7 & -6.3 & -5.1 & -6.6 & -5.7 & -3.3 & -5.4 & -6.3 \\
\hline $\begin{array}{l}\text { 10-methyl-e-11-tridecen- } \\
\text { 1-ol propionate }\end{array}$ & -5.2 & -4.7 & -5.2 & -4.1 & -4.7 & -4.5 & -2.9 & -4.9 & -4.3 \\
\hline 1-decanol, 2-hexyl- & -5.2 & -4.8 & -5.2 & -4.4 & -4.7 & -4.4 & -2.9 & -5.3 & -4.7 \\
\hline 1-decanol, 2-methyl- & -5 & -4.7 & -5 & -4.1 & -4.4 & -3.9 & -2.7 & -4.8 & -4.6 \\
\hline 1-decen-4-yne, 2-nitro- & -5.6 & -5 & -4.9 & -4.9 & -4.9 & -4.3 & -3.5 & -5.7 & -5.2 \\
\hline 1-eicosanol & -5.1 & -3.9 & -4.4 & -3.8 & -4.2 & -3.8 & -2.7 & -4.6 & -4.5 \\
\hline 1-heptadecanol & -4.8 & -4.4 & -4.7 & -4 & -4.5 & -4.2 & -3 & -4.4 & -4.7 \\
\hline 1-nonadecanol & -3.9 & -4.3 & -4.4 & -4.1 & -4.2 & -3.6 & -2.7 & -5 & -4.2 \\
\hline $\begin{array}{l}\text { 2-(prop-2- } \\
\text { enoyloxy)tetradecane }\end{array}$ & -5.2 & -5.5 & -5.3 & -4.5 & -5.2 & -3.7 & -3.1 & -5.6 & -4.8 \\
\hline $\begin{array}{l}2,3,5,8- \\
\text { tetramethyldecane }\end{array}$ & -5.1 & -4.4 & -5.2 & -4.2 & -4.9 & -4 & -3 & -4.8 & -4.7 \\
\hline $\begin{array}{l}2,6,11- \\
\text { trimethyldodecane }\end{array}$ & -5.5 & -4.4 & -4.9 & -4.2 & -4.3 & -4.2 & -3.2 & -4.7 & -4.4 \\
\hline $\begin{array}{l}\text { 2-azido-2,4,4,6,6- } \\
\text { pentamethylheptane }\end{array}$ & -5.2 & -5.4 & -5.4 & -5.6 & -4.8 & -4.1 & -3.6 & -5.4 & -4.9 \\
\hline 2-butyl-1-octanol & -5.2 & -5 & -5.1 & -5.6 & -4.7 & -4 & -2.8 & -4.7 & -3.8 \\
\hline $\begin{array}{l}\text { 2-Cyclohexen-1-ol, 2- } \\
\text { methyl-5-(1- } \\
\text { methylethenyl)-, (1S)- }\end{array}$ & -6 & -5.5 & -5.6 & -6.6 & -5.3 & -4.1 & -3.7 & -5.5 & -5.2 \\
\hline 2-dodecanol & -4.9 & -4.6 & -4.6 & -4.3 & -4.6 & -3.8 & -2.9 & -5.1 & -4.7 \\
\hline 2-hexyl-1-octanol & -5.2 & -4.7 & -4.9 & -6.1 & -4.3 & -4.7 & -2.9 & -4.8 & -4.6 \\
\hline $\begin{array}{l}\text { 3,4-Dihydro-1h- } \\
\text { isoquinoline-2- } \\
\text { carboxamidine } \\
\text { hydrochloride }\end{array}$ & -6.4 & -6.6 & -6.6 & -7.4 & -6.3 & -3.8 & -4.4 & -6.4 & -6.3 \\
\hline $\begin{array}{l}\text { 3- } \\
\text { hexadecyloxycarbonyl- } \\
\text { 5-(2-hydroxyethyl)-4- } \\
\text { methylimidazolium ion }\end{array}$ & -4.6 & -4.8 & -4.5 & -4.8 & -5.1 & -4.3 & -2.8 & -5.3 & -4.5 \\
\hline $\begin{array}{l}\text { 5-ethyl-2,2,3- } \\
\text { trimethylheptane }\end{array}$ & -5.2 & -5.2 & -4.9 & -4.5 & -4.8 & -4.7 & -3.3 & -5.1 & -4.3 \\
\hline
\end{tabular}




\begin{tabular}{lccccccccc}
$\begin{array}{l}\text { 8-amino-6- } \\
\text { methoxyquinoline }\end{array}$ & -6.3 & -5.7 & -6.5 & -7.1 & -5.8 & -4 & -3.6 & -5.5 & -5.4 \\
\hline Azulene & -5.8 & -5.6 & -5.9 & -6.8 & -5.8 & -4.9 & -4.2 & -5.6 & -5.3 \\
$\begin{array}{l}\text { Benzene, 1-methyl-4-(1- } \\
\text { methylethenyl)- }\end{array}$ & -5.9 & -5.5 & -5.4 & -5.4 & -5 & -4.7 & -3.8 & -5.3 & -5.2 \\
$\begin{array}{l}\text { Benzene, 2-(butenyl)-5- } \\
\begin{array}{l}(1,1-d i m e t h y l e t h y l)-1,3- \\
\text { dimethyl- }\end{array}\end{array}$ & -5.4 & -5.2 & -5.2 & -6.1 & -5.2 & -4.5 & -3.7 & -5.3 & -5.3 \\
\hline
\end{tabular}

$\begin{array}{llllllllll}\text { Cyclooctaneacetic acid, } \quad-6.4 & -5.7 & -5.9 & -7.3 & -5.9 & -4.6 & -3.7 & -6.2 & -5.2\end{array}$ 2-oxo-

$\begin{array}{lccccccccc}\text { Decane } & -4.8 & -4.4 & -4.4 & -4.2 & -4.4 & -3.1 & -2.6 & -5.1 & -4.4 \\ \text { Decane 4-methyl- } & -4.6 & -4 & -4 & -3.9 & -4.5 & -3.6 & -2.5 & -4.8 & -4.4 \\ \begin{array}{l}\text { D-glucose, cyclic } \\ \text { ethylene mercaptal, } \\ \text { pentaacetate }\end{array} & -5.9 & -6.3 & -5.6 & -4.3 & -5.7 & -4.2 & -4.1 & -5.3 & -4.8 \\ \end{array}$

\begin{tabular}{|c|c|c|c|c|c|c|c|c|c|}
\hline Dodecanal & -4.7 & -4.6 & -4.3 & -3.8 & -4.1 & -3.8 & -3 & -4.9 & -4.4 \\
\hline E-2, 3-epoxycarane & -5.9 & -5.7 & -5.7 & -7 & -5.5 & -4.3 & -3.2 & -5.5 & -4.9 \\
\hline Eicosane & -5.1 & -4.5 & -4.4 & -3.7 & -4.5 & -3.7 & -2.9 & -4.4 & -4.5 \\
\hline Heptacosane & -3.8 & -4.3 & -4.7 & -3.9 & -4.3 & -3.5 & -2.6 & -4.1 & -4.5 \\
\hline Hexadecane & -4.7 & -4.3 & -4.6 & -4.5 & -4.1 & -3.6 & -3 & -4.6 & -4.5 \\
\hline Isopinocarveol & -5.5 & -5.4 & -5.3 & -7.1 & -5.5 & -4.3 & -3.3 & -5.2 & -5 \\
\hline $\begin{array}{l}\text { Methoxyacetic acid, 2- } \\
\text { tetradecyl ester }\end{array}$ & -5.3 & -4.8 & -4.9 & -4.3 & -4.8 & -4.1 & -3.2 & -4.8 & -4.6 \\
\hline $\begin{array}{l}\text { Methoxyacetic acid, 3- } \\
\text { tridecyl ester }\end{array}$ & -5.2 & -4.6 & -4.7 & -3.9 & -4.8 & -4.1 & -3 & -4.8 & -4.6 \\
\hline $\begin{array}{l}\text { Methoxyacetic acid, } \\
\text { pentadecyl ester }\end{array}$ & -4.4 & -4.2 & -4.7 & -3.7 & -4.7 & -3.9 & -2.9 & -4.8 & -4.2 \\
\hline $\begin{array}{l}\text { Methyl 3- } \\
\text { hydroxytetradecanoate }\end{array}$ & -5.4 & -4.6 & -4.8 & -4.4 & -4.6 & -4.4 & -2.8 & -4.8 & -4.5 \\
\hline $\begin{array}{l}\mathrm{N}, \mathrm{n}^{\prime}- \\
\text { methylenebisacrylamide }\end{array}$ & -5.1 & -4.4 & -4.6 & -4.6 & -4.7 & -3.6 & -3.1 & -4.5 & -4.2 \\
\hline N-hexadecanoic acid & -4.5 & -4.6 & -4.8 & -3.9 & -4.5 & -3.8 & -3.2 & -4.8 & -4.9 \\
\hline Nonadecane & -4.6 & -4.1 & -4.2 & -4 & -4.1 & -3.6 & -2.6 & -4.5 & -4.9 \\
\hline Octacosane & -4.5 & -3.8 & -4.5 & -3.9 & -4 & -3.8 & -2.8 & -4.6 & -4.8 \\
\hline $\begin{array}{l}\text { Octadecanoic acid, } \\
\text { methyl ester }\end{array}$ & -5.5 & -4.3 & -4.6 & -5.8 & -4.4 & -3.8 & -2.9 & -4.8 & -5 \\
\hline
\end{tabular}




\begin{tabular}{|c|c|c|c|c|c|c|c|c|c|}
\hline O-xylene & -5 & -5 & -5 & -4.1 & -5 & -4.2 & -3.6 & -4.7 & -4.5 \\
\hline $\begin{array}{l}\text { Pentadecanoic acid, 14- } \\
\text { methyl-, methyl ester }\end{array}$ & -5.2 & -4.1 & -4.6 & -4 & -4.6 & -3.9 & -2.9 & -5 & -4.8 \\
\hline $\begin{array}{l}\text { Pentanoic acid, octyl } \\
\text { ester }\end{array}$ & -4.9 & -4.3 & -4.5 & -5.2 & -4.7 & -3.6 & -2.9 & -4.6 & -4.5 \\
\hline $\begin{array}{l}\text { Phenol,2,4- } \\
\text { bis(1,1dimethylethyl)- }\end{array}$ & -6.3 & -5.8 & -6 & -5.9 & -5.6 & -5 & -4.1 & -6.3 & -5.5 \\
\hline $\begin{array}{l}\text { Sulfurous acid, 2- } \\
\text { ethylhexyl nonyl ester }\end{array}$ & -4.6 & -4.7 & -5 & -3.8 & -4.6 & -4.3 & -2.6 & -4.6 & -4.6 \\
\hline Tetracosane & -3.5 & -4.9 & -4.4 & -3.9 & -4.5 & -3.7 & -2.7 & -4.9 & -5.1 \\
\hline Tetradecane & -4.7 & -4.1 & -4.3 & -4.2 & -4.5 & -3.6 & -2.8 & -4.5 & -4.5 \\
\hline Tetradecanoic acid & -5.2 & -4.4 & -4.8 & -5.5 & -4.3 & -3.7 & -3.3 & -5.1 & -4.4 \\
\hline Tridecane & -4.7 & -4.1 & -4.1 & -3.9 & -4.2 & -3.4 & -2.5 & -4.9 & -4.4 \\
\hline Undecane & -4.8 & -4.3 & -4.2 & -4.1 & -4.3 & -3.6 & -2.6 & -5 & -4.1 \\
\hline $\begin{array}{l}\text { Z-10-tetradecen-1-ol } \\
\text { acetate }\end{array}$ & -5.3 & -4.5 & -4.8 & -4.4 & -4.5 & -3.9 & -3.2 & -5 & -5 \\
\hline
\end{tabular}

Figures 
CD34

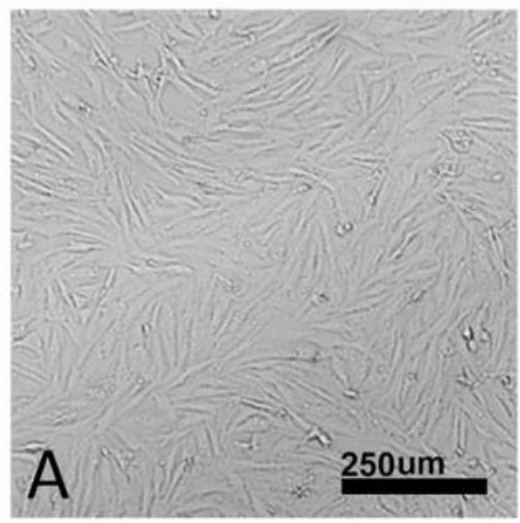

CD44

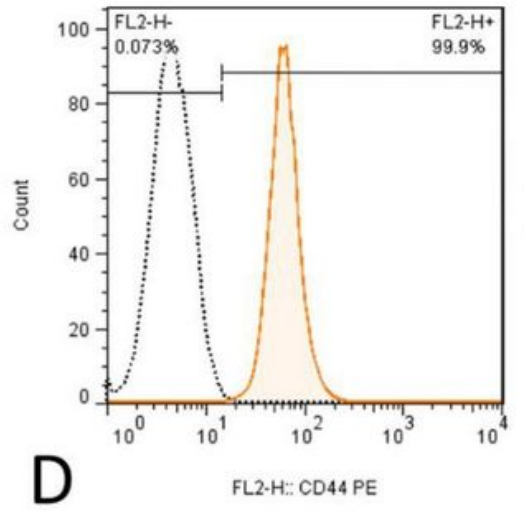

D

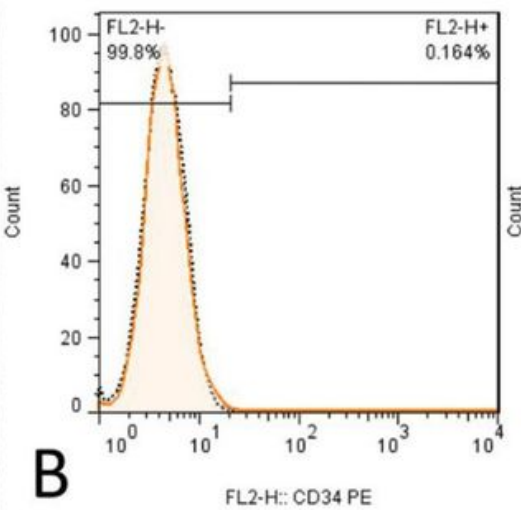

CD73

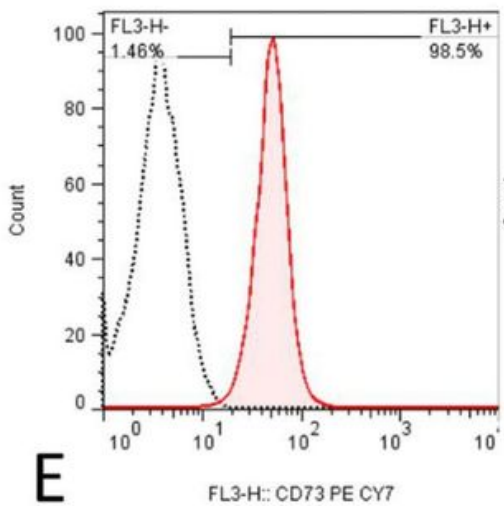

CD45

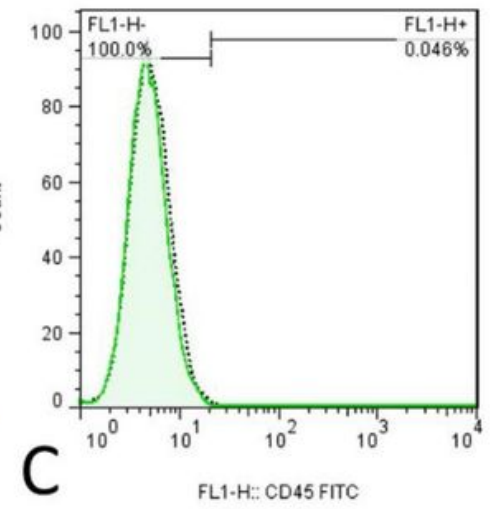

CD90

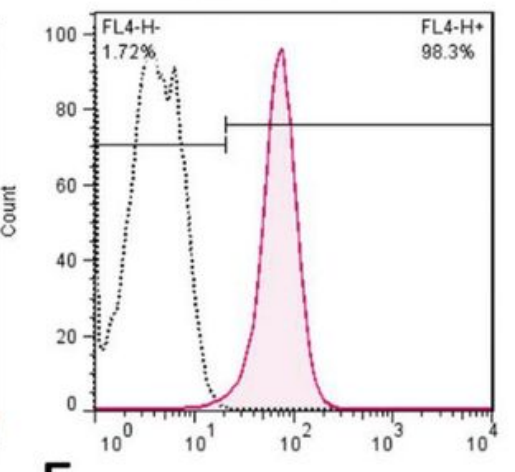

$\mathrm{F}$
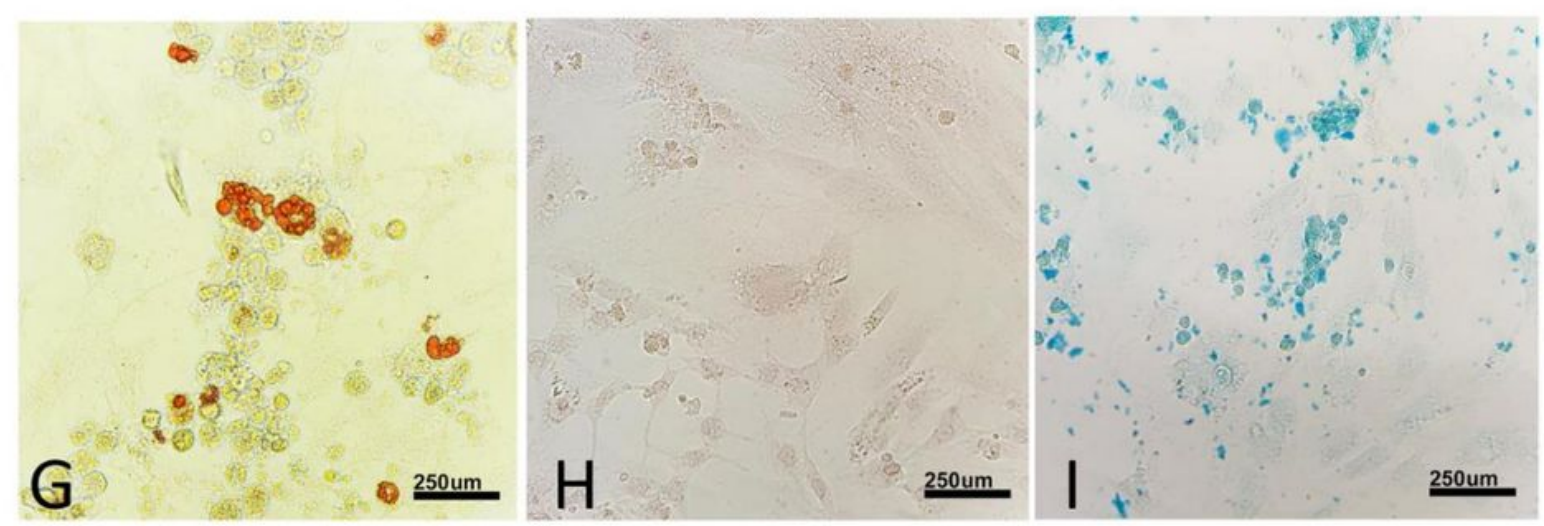

Figure 1.

\section{Figure 1}

Characterization of human umbilical cord mesenchymal stem cells (hUC-MSCs). A) hUC-MSCs morphology. Flow cytometric histograms showing the immunophenotype of hUC-MSCs. B and C) The hUC-MSCs are negative for the hematopoietic line markers CD34 and CD45. D-F) Analyzed hUC-MSCs are positive for CD44, CD73, and CD90, which are considered to be markers of MSCs. FITC, fluorescein isothiocyanate; PE, phycoerythrin. G-I) Differentiation of hUC-MSCs to adipogenic differentiation in which the cells were stained 
with Oil Red O, osteogenic differentiation in which the cells were stained with Alizarin red, and chondrogenic differentiation that the cells were stained with Alcian blue.
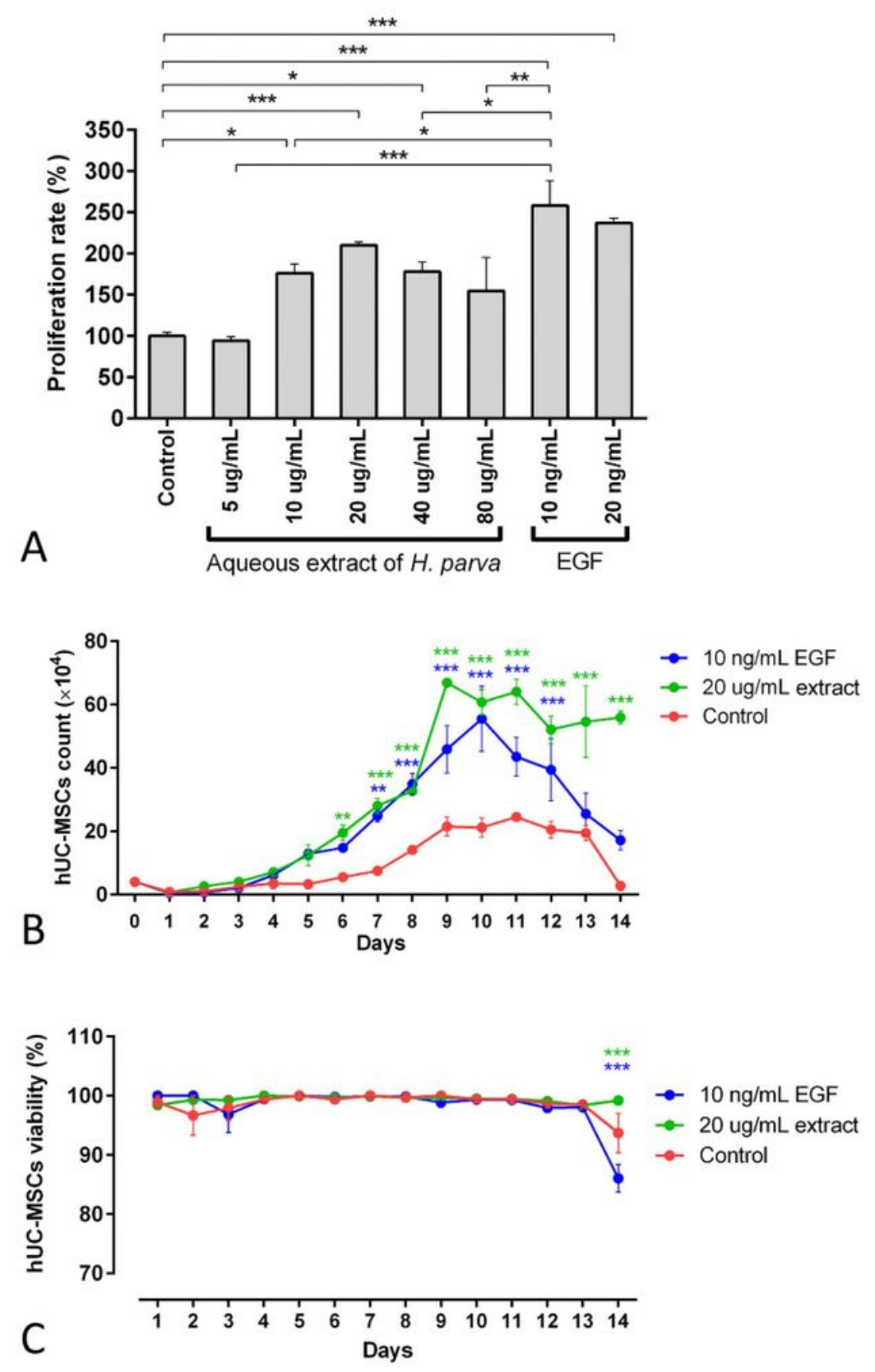

Figure 2.

\section{Figure 2}

Mean and standard errors of cell proliferation rate (A), cell count (B), and cell viability (C) of human umbilical cord mesenchymal stem cells (hUC-MSCs) after exposure to aqueous extract of sea cucumber (Holothuria parva) or epidermal growth factor (EGF). *P $<0.05$; $* \star P<0.01$; $* \star \star P ~<0.001$. 


\section{Extract}

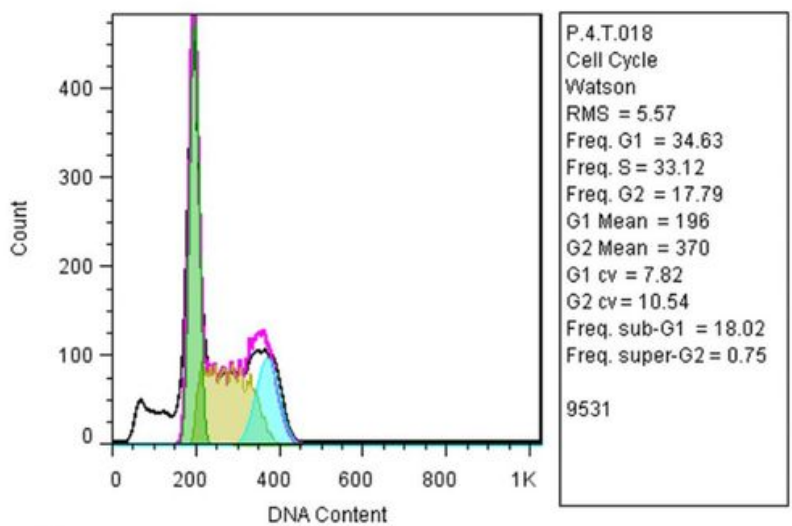

A

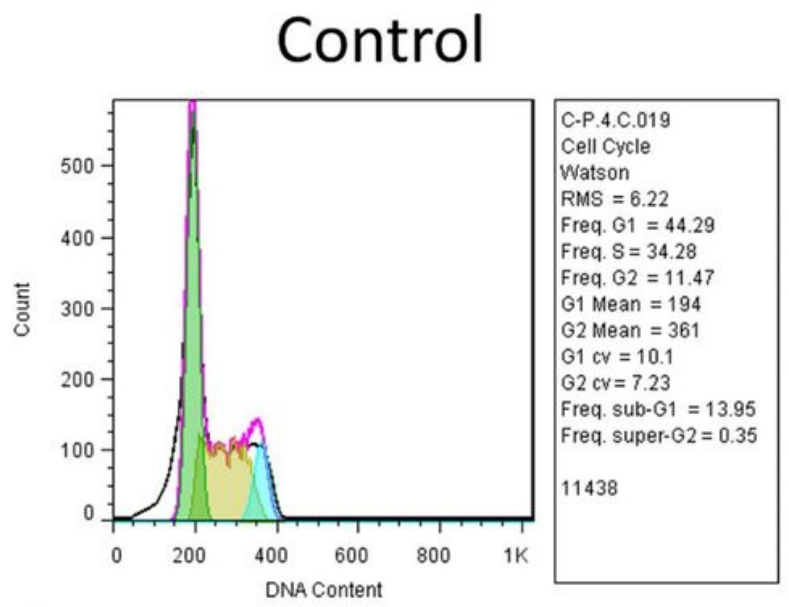

C

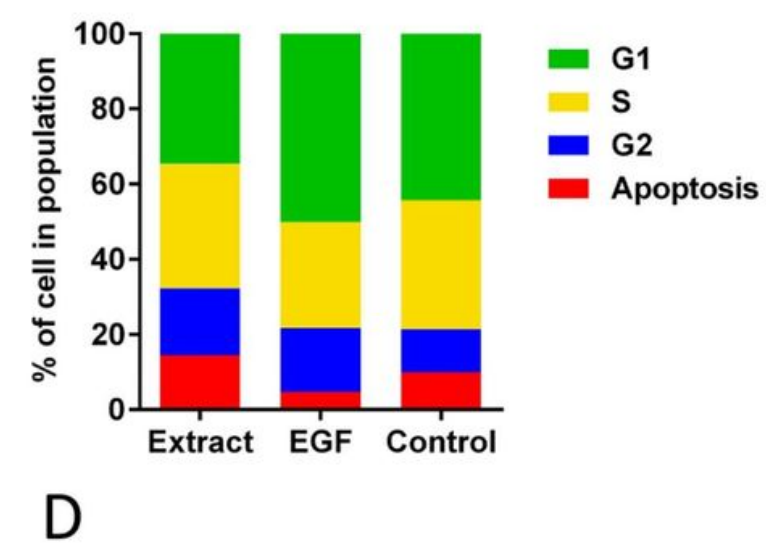

Figure 3.

\section{Figure 3}

Cell cycle assay of human umbilical cord mesenchymal stem cells (hUC-MSCs) after exposure to aqueous extract of sea cucumber (Holothuria parva) or epidermal growth factor (EGF). 

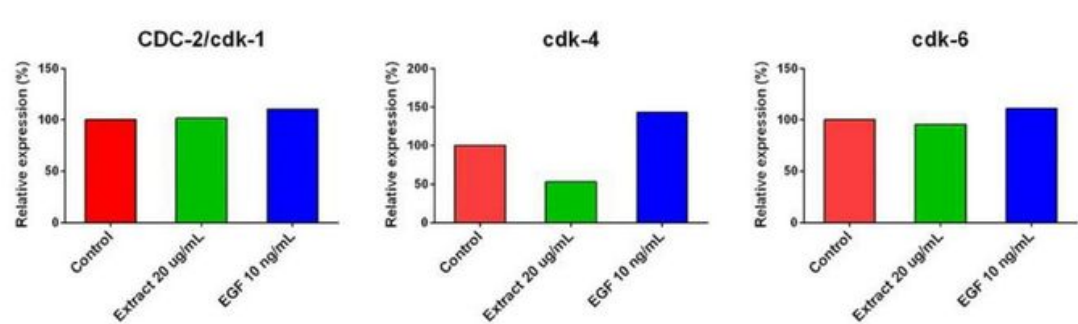

cyclin D1
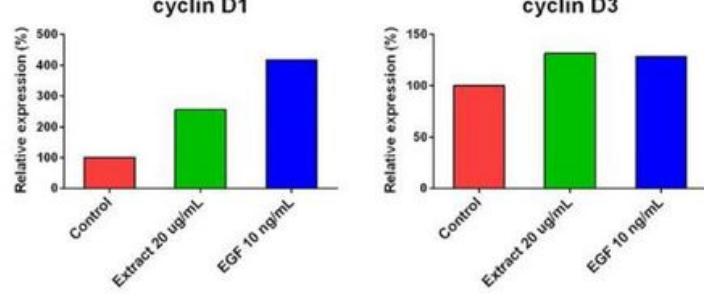

p21
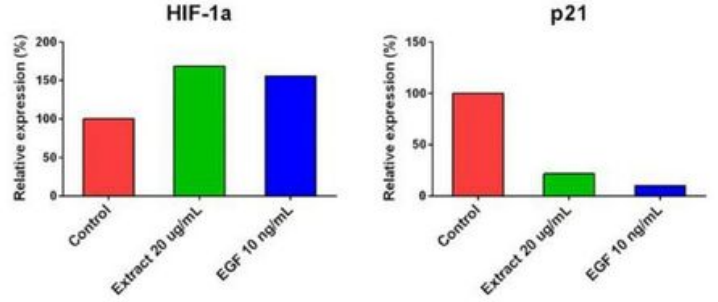

ERK1/2
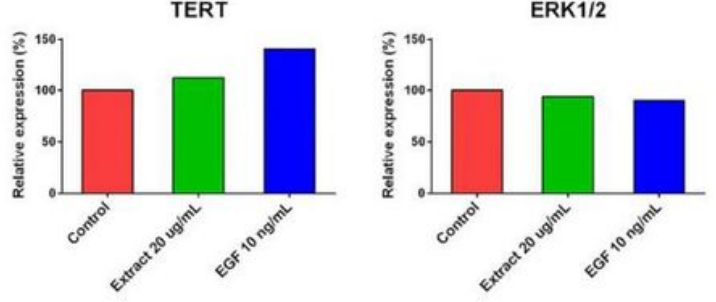

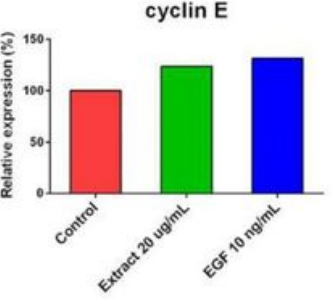

PCNA

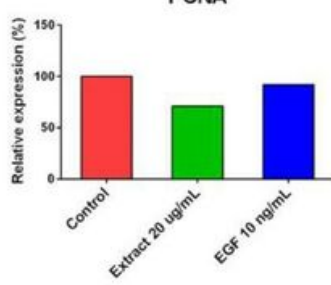

B-actin

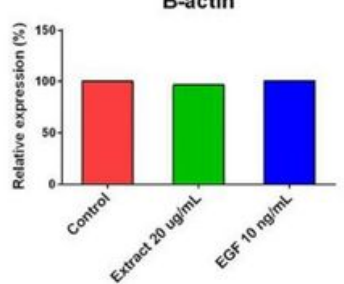

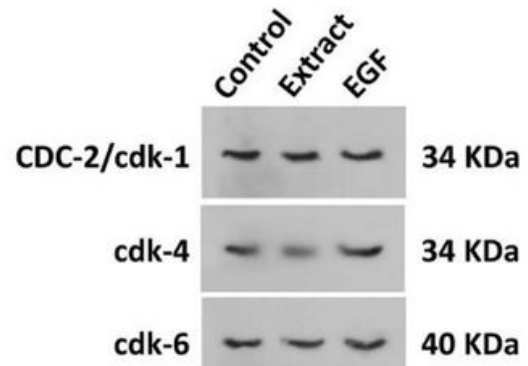

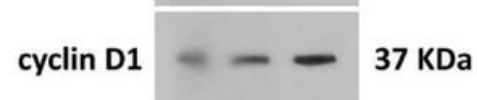

cyclin D3 - - $33 \mathrm{KDa}$

cyclin E $--53 \mathrm{KDa}$

HIF-1a $--132 \mathrm{KDa}$

p21 $-21 \mathrm{KDa}$

PCNA $-\ldots 36 \mathrm{KDa}$

TERT - - - $130 \mathrm{KDa}$

$\mathrm{ERK} 1 / 2= \pm= \pm 2-44 \mathrm{KDa}$

B-actin $---42 \mathrm{KDa}$

Figure 4.

\section{Figure 4}

Expression of proliferation-related proteins after treating of human umbilical cord mesenchymal stem cells (hUC-MSCs) with aqueous extract of sea cucumber (Holothuria parva) or epidermal growth factor (EGF). 


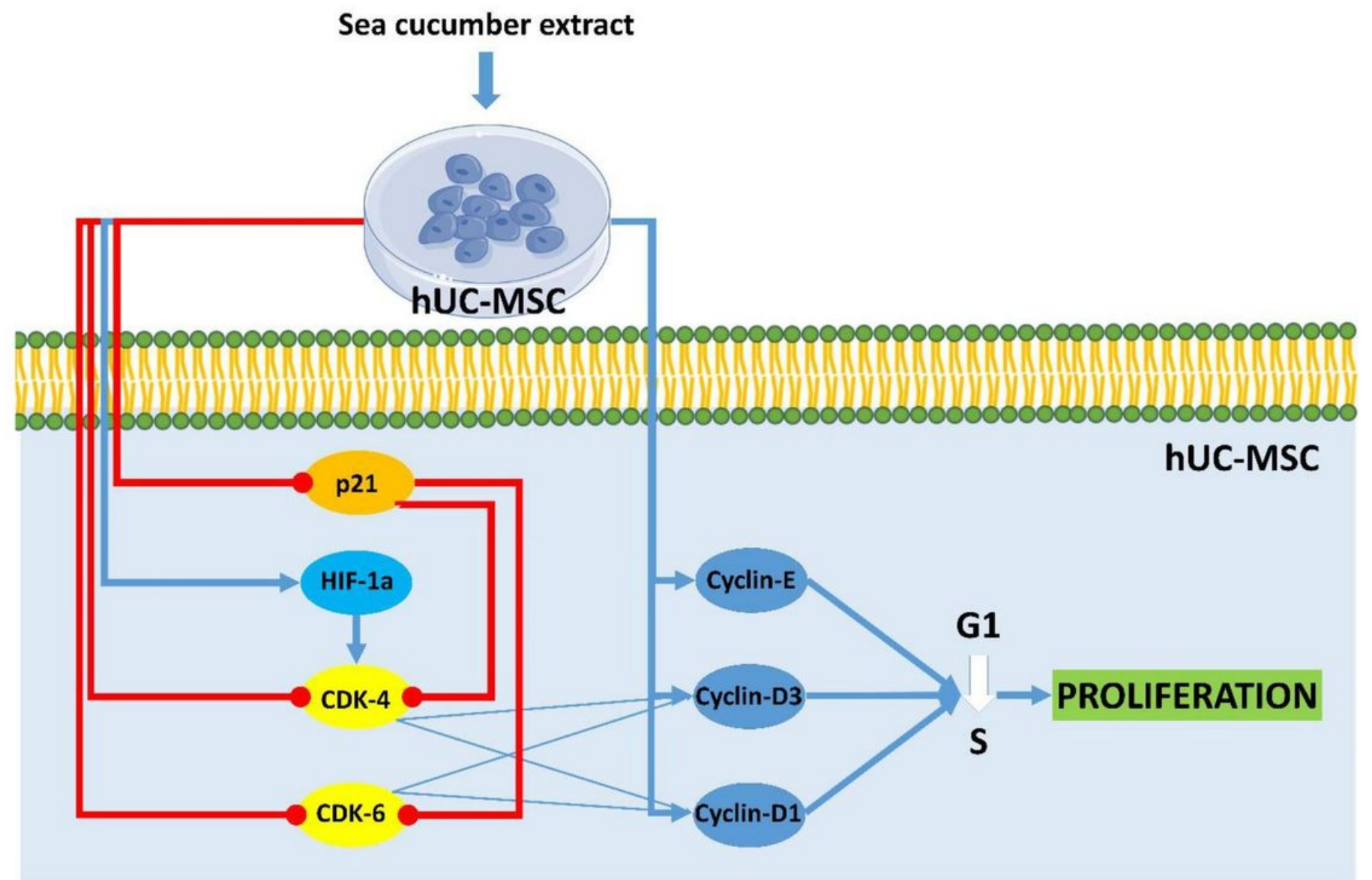

Figure 5.

Figure 5

Aqueous extract of sea cucumber (Holothuria parva) induces proliferation in human umbilical cord mesenchymal stem cells (hUC-MSCs). Small colorful dots, red lighting, blue arrows and red hammerheadlines represent the extract bioactive molecules were detected by docking technique, the extract-induced stimulus, direct reactions and each inhibiting reaction, respectively.

\section{Supplementary Files}

This is a list of supplementary files associated with this preprint. Click to download.

- Supplementaryfile.docx 